\title{
Influence of the Steric Demand of Coligands on the Catalytic Activity of Nickel(II) Complexes in the Copolymerization of Ethene and Carbon Monoxide
}

\author{
Monika M. Lindner, ${ }^{1}$ Udo Beckmann, ${ }^{1}$ Walter Frank, ${ }^{2}$ and Wolfgang Kläui ${ }^{1}$ \\ ${ }^{1}$ Lehrstuhl I: Bioanorganische Chemie und Katalyse, Institut für Anorganische Chemie und Strukturchemie, \\ Heinrich-Heine-Universität Düsseldorf, Universitätsstraße 1, 40225 Düsseldorf, Germany \\ ${ }^{2}$ Lehrstuhl II: Material- und Strukturforschung, Institut für Anorganische Chemie und Strukturchemie, \\ Heinrich-Heine-Universität Düsseldorf, Universitätsstraße 1, 40225 Düsseldorf, Germany \\ Correspondence should be addressed to Monika M. Lindner; monika.lindner@uni-duesseldorf.de
}

Received 31 August 2012; Accepted 20 September 2012

Academic Editors: M. Joshaghani and A. J. Pardey

Copyright (C) 2013 Monika M. Lindner et al. This is an open access article distributed under the Creative Commons Attribution License, which permits unrestricted use, distribution, and reproduction in any medium, provided the original work is properly cited.

\begin{abstract}
The copolymerization of ethene and carbon monoxide can be catalyzed with square planar arenidotriphenylphosphane nickel(II) complexes containing an $\mathrm{N}, \mathrm{O}$-chelate ligand. To examine the influence of the phosphorus ligand on the catalytic activity, five new nickel(II) complexes with $P$-ligands of different basicities and different steric demands were synthesized and fully characterized including the determination of the crystal structures of three of the complexes. The investigation of the catalytic activity of the new compounds showed a decisive influence of the steric properties of the $P$-ligand. A minimum steric demand is essential to ensure catalytic activity.
\end{abstract}

\section{Introduction}

Phosphanes are widely used as ligands in catalysts for reactions such as hydroformylations, hydrogenations, and oligomerizations in organometallic and coordination chemistry. A large variety of substituents leads to a broad scope of different phosphorus ligands on the one hand, for example, tertiary phosphanes and phosphites, and on the other hand makes the successive variation of the substituents possible to create $P$-ligands with fine-tuned properties. A well-directed variation of the spectator ligands allows to control activity, selectivity, and productivity of a catalyst complex [1-5].

The coordination properties of $P$-ligands are determined by the electronic effects of the substituents on the phosphorus atom, arising from the substituents' inductive effects, and by the steric demand of the substituents. A positive inductive effect leads to a high electron density at the phosphorus atom, while a negative inductive effect reduces the electron density at the $P$-atom which also affects the electronic situation at the metal centre. The electronic effects thus influence the basicity of the phosphorus atom. The basicity of phosphanes has been widely documented in the literature [6-11]. A useful concept to assess the basicity of a $P$-ligand is the electronic parameter defined by Tolman in 1976 who used the frequency of the $\mathrm{A}_{1} \mathrm{CO}$ stretching vibration in $\mathrm{Ni}(\mathrm{CO})_{3} \mathrm{~L}$ to rank different $P$ ligands $\mathrm{L}$ in a series $[12,13]$. The more basic a ligand, the lower is the CO stretching frequency and the higher is the coordination ability of the ligand. The steric properties of a $P$-ligand were also described by Tolman in his concept of the cone angle $[12,14]$ which offers a good estimation of the size of a $P$-ligand with small ligands showing better coordination abilities.

Phosphanes are ubiquitous ligands in transition metal catalysts. By far the most popular phosphane for large scale processes is triphenylphosphane [3] which is also contained in nickel catalysts (as depicted in Figure 1) for the synthesis of polyketones via ethene/carbon monoxide copolymerization [15-19].

The production of aliphatic polyketones on an industrial scale is based on palladium, and palladium catalysts are also 


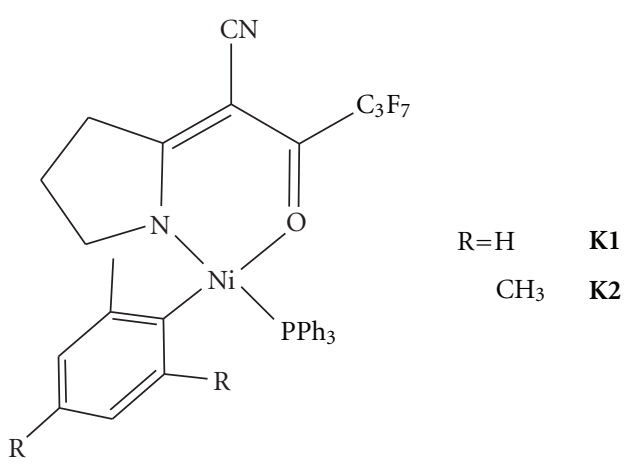

FIGURE 1: Active nickel catalysts for the copolymerization reaction of ethene and carbon monoxide [15-19].

being investigated for this process ([20-26] and references cited therein). However, since the expensive noble metal catalyst remains in the polymer and is therefore lost for further catalyst cycles, nickel complexes could provide a cheaper alternative. In terms of efficiency the nickel complexes $\mathbf{K} \mathbf{1}$ and K2 shown in Figure 1 with a bidentate $\mathrm{N}, \mathrm{O}$-chelate ligand $\mathrm{L}$ are the best ones to date. To investigate the influence of the different substituents on the $\mathrm{N}, \mathrm{O}$-chelate ligand we varied the groups of the $\mathrm{N}, \mathrm{O}$-chelate ligand as well as the ring size of the heterocycle $[19,27]$. As deactivation studies showed that the triphenylphosphane ligand does not dissociate during the catalytic polymerization [18] but dissociates during the decomposition process [28], we decided to investigate the influence of the $P$-ligand on the catalytic activity. In this work we report on the variation of the $P$-ligand on the basis of complex K2, including the synthesis and characterization of the nickel complexes with different $P$-ligands and the studies of the new compounds as catalysts for the copolymerization of ethene and CO. Examples for the influence of different steric and electronic properties of phosphane ligands on the catalytic activity of nickel and palladium complexes are documented in the literature [29-33]. Generally it depends on the type of catalytic reaction whether steric or electronic effects are more important.

\section{Results and Discussion}

2.1. Synthesis of the Complexes. We developed two different routes for the synthesis of the complexes with different $P$ ligands as depicted in Scheme 1. A simple, but efficient, method is the ligand substitution reaction starting from the catalyst complex K2 and exchanging triphenylphosphane for the favoured $P$-ligand denoted in Scheme 1 as reaction pathway A. Complex K2 is dissolved in toluene, 2 eq. of the $P$ ligand (phosphane or phosphite) are added and the mixture is stirred at room temperature. The substitution reaction is monitored by ${ }^{31} \mathrm{P}\left\{{ }^{1} \mathrm{H}\right\}$ NMR spectroscopy. After completion of the reaction, the product complex can be separated from the triphenylphosphane that is released during the reaction by column chromatography.

The readiness of a $P$-ligand to replace triphenylphosphane as ligand in the nickel complex $\mathbf{K} 2$ can be correlated to the steric demand and the basicity of the $P$-ligand. The lower the steric demand and the higher the basicity of the ligand is, the more willingly triphenylphosphane can be substituted. Full conversion was found for phosphanes that are "better" ligands than triphenylphosphane so that the driving force for the reaction results from the formation of the more stable complex. A condition for this is a ligand comprising a higher basicity and less steric demand, thus a smaller ligand cone angle $(\Theta<$ $145^{\circ}$ ) than that of triphenylphosphane, for example, nbutyldiphenylphosphane, di-n-butylphenylphosphane, and tri-n-butylphosphane (cf. Table 3). With $P$-ligands possessing a lower basicity and/or a higher steric demand full conversion cannot be reached.

A drawback of the substitution method is the necessity of relatively large quantities of the phosphane to reach full conversion. This method is therefore suitable for phosphanes that can either be bought cheaply or prepared easily.

The conventional procedure is a bottom-up approach for the synthesis of the catalyst complex starting from nickel(II) dibromide and two equivalents of the $P$-ligand as previously described for the triphenylphosphane complex K2 [17], marked in Scheme 1 as reaction pathway B1. First a Venanzitype complex $\left[\mathrm{NiBr}_{2}\left(\mathrm{PR}^{\mathrm{a}} \mathrm{R}^{\mathrm{b}} \mathrm{R}^{\mathrm{c}}\right)_{2}\right]$ is synthesized (Scheme 1 , reaction step B1, and Figure 2 [34-40]). Complexes of this type containing a tetrahedral nickel centre with two halides and two triphenylphosphane ligands were first investigated by Venanzi in 1958 [34]. Depending on the coordination properties of the ligand, the reaction procedure has to be adapted. When using ligands with good coordination properties that are sufficiently basic and sterically not too demanding, it suffices to suspend nickel(II) dibromide in tetrahydrofuran. The new complex is instantly formed on addition of the ligand, indicated by the colour change from the orange-brown colour of $\mathrm{NiBr}_{2}$ to the forming complex with a very intensive colour depending on the ligand. To coordinate ligands with a bigger cone angle or less basicity, the poorly soluble nickel(II) dibromide needs to be dissolved before adding the ligand. The Venanzi-type complexes can be isolated as intensively coloured solids by removing the solvent in vacuo, albeit this reaction was usually carried out in situ. Depending on the ligand, the Venanzi-type complexes are either tetrahedral and paramagnetic or square-planar and diamagnetic [35-37, 41, 42].

In the next step (B2 in Scheme 1) the Venanzi-type complex is reacted with mesitylenido magnesium bromide in a Grignard reaction to introduce the arenido ligand [43]. During the workup the mixture is hydrolysed with methanol and the product complex-depending on its solubility-either precipitated, extracted, or crystallized at low temperatures. All [NiBrMes $\left(\mathrm{PR}^{\mathrm{a}} \mathrm{R}^{\mathrm{b}} \mathrm{R}^{\mathrm{c}}\right)_{2}$ ] complexes (Figure 3) are diamagnetic and square-planar, and they can be easily characterized by NMR spectroscopy.

To synthesize the target complex $\left[\mathrm{Ni}(\mathrm{L}) \mathrm{Mes} \mathrm{R}^{\mathrm{a}} \mathrm{R}^{\mathrm{b}} \mathrm{R}^{\mathrm{c}}\right.$ ] the $\mathrm{N}, \mathrm{O}$-chelate ligand $\mathrm{HL}$ is coordinated in the last step to the precursor complex $\left[\mathrm{NiBrMesPR} \mathrm{R}^{\mathrm{a}} \mathrm{R}^{\mathrm{b}} \mathrm{R}^{\mathrm{c}}\right.$ ] as shown in Scheme 1 (reaction step B3). The N,O-chelate ligand $\mathbf{H L}$ is deprotonated with sodium bis(trimethylsilyl) amide and 


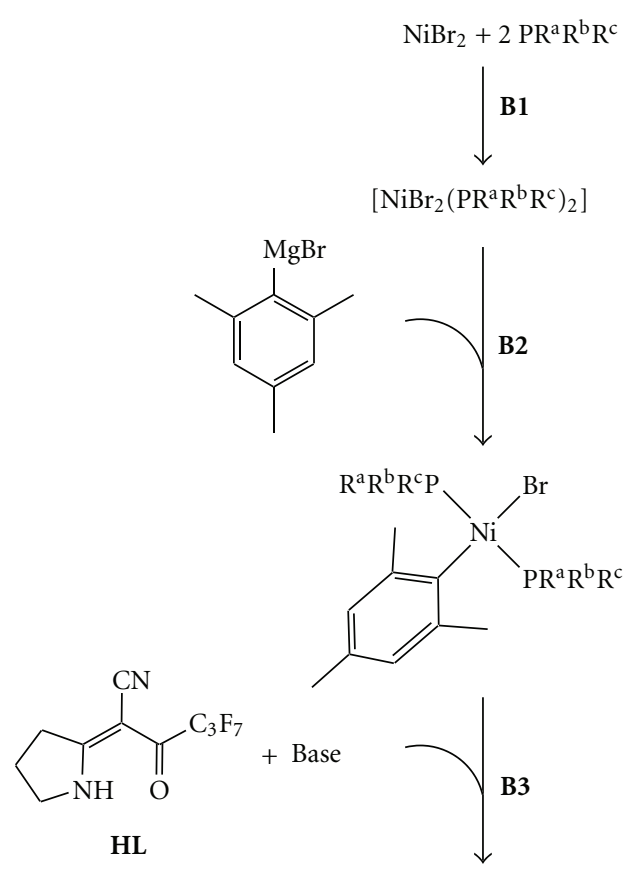<smiles>Cc1cc(C)c([N+]2(c3ccccc3)OC(C(F)(F)F)C(C#N)=C3CCCN32)c(C)c1</smiles>

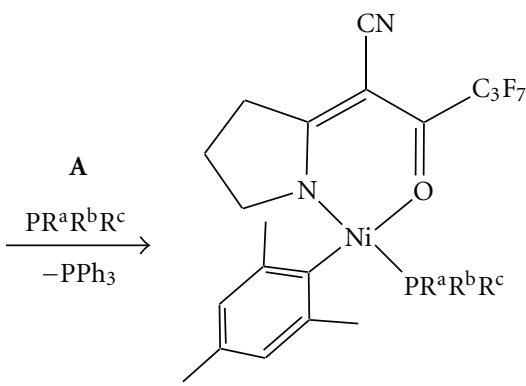

K2

Scheme 1: Reaction routes for the synthesis of the nickel complexes with different $P$-ligands (reaction pathway (A): substitution of triphenylphosphane in complex $\mathbf{K} \mathbf{2}$ by the desired $P$-ligand, reaction pathway (B): bottom-up approach starting from nickel dibromide and the $P$-ligand).

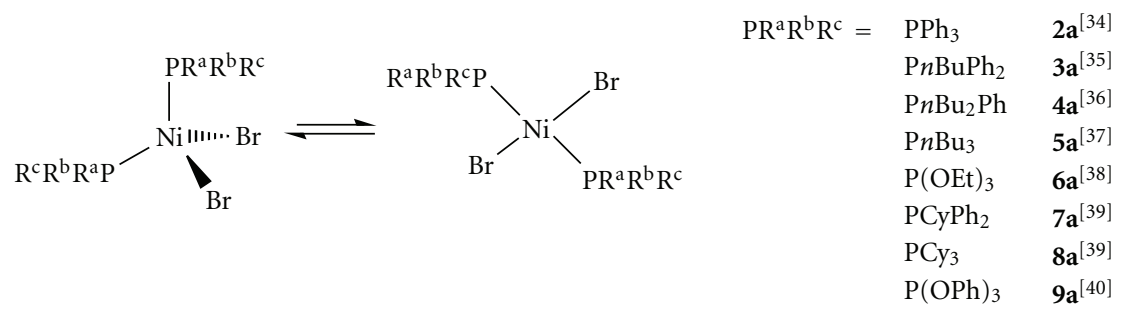

Figure 2: Synthesized Venanzi-type complexes.

the progress of the reaction is monitored by ${ }^{31} \mathrm{P}\left\{{ }^{1} \mathrm{H}\right\} \mathrm{NMR}$ spectroscopy. The separation of the complexes from the released $P$-ligand is carried out by column chromatography on neutral alumina or crystallization at low temperatures. All complexes (Figure 4) show a yellow to orange or brown colour and were fully characterized.

Table 1 shows the chemical shifts of the utilized $P$-ligands as well as those of the synthesized precursor and catalyst complexes in the ${ }^{31} \mathrm{P}\left\{{ }^{1} \mathrm{H}\right\}$ NMR spectrum. Comparing, for example, the series of compounds in which the phenyl substituents at the $P$-ligand are exchanged one by one for n-butyl substituents, the same trend of a gradual high field shift can be discovered for the $P$-ligands $\left(\mathrm{PPh}_{3}, \mathrm{P}_{n \mathrm{Bu}} \mathrm{Ph}_{2}\right.$, $\mathrm{P} n \mathrm{Bu}_{2} \mathrm{Ph}$, and $\left.\mathrm{P} n \mathrm{Bu}_{3}\right)$, the precursor complexes $\mathbf{2 b}, \mathbf{3 b}, \mathbf{4 b}$, and $\mathbf{5 b}$, and the catalyst complexes $\mathrm{K} 2, \mathrm{~K} 3, \mathrm{~K} 4$, and $\mathrm{K} 5$.

The crystal structures of the complexes K5, K6, and K7 were determined by X-ray crystallography as depicted in Figures 5, 6, and 7. 


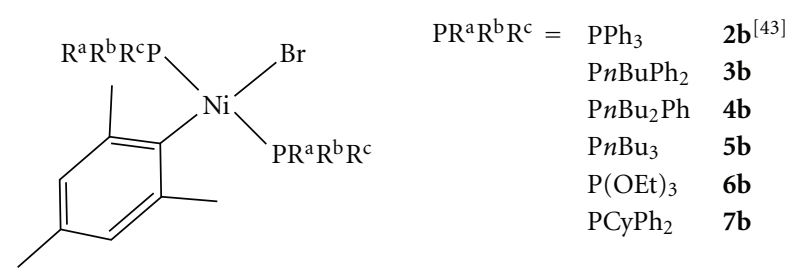

FIgURE 3: Synthesized complexes of the formula $\left[\mathrm{NiBrMes}\left(\mathrm{PR}^{\mathrm{a}}\right.\right.$ $\left.\left.\mathrm{R}^{\mathrm{b}} \mathrm{R}^{\mathrm{c}}\right)_{2}\right]$.<smiles>[R17]CCN1N2CCCC2C(C#N)=C(C(C)(C)C)O[N+]1([R17])c1c(C)cc(C)cc1C</smiles>

$$
\begin{aligned}
& \mathrm{PR}^{\mathrm{a}} \mathrm{R}^{\mathrm{b}} \mathrm{R}^{\mathrm{c}}=\mathrm{PPh}_{3} \quad \mathrm{~K}^{[17]} \\
& \mathrm{P} n \mathrm{BuPh}_{2} \quad \mathrm{~K} 3 \\
& \mathrm{P} n \mathrm{Bu}_{2} \mathrm{Ph} \quad \mathrm{K} 4 \\
& \mathrm{P}_{n} \mathrm{Bu}_{3} \quad \mathrm{~K} 5 \\
& \mathrm{P}(\mathrm{OEt})_{3} \quad \text { K6 } \\
& \mathrm{PCyPh}_{2} \quad \text { K7 }
\end{aligned}
$$

FIgURE 4: Synthesized catalyst complexes of the formula $\left[\mathrm{Ni}(\mathbf{L}) \mathrm{MesPR}^{\mathrm{a}} \mathrm{R}^{\mathrm{b}} \mathrm{R}^{\mathrm{c}}\right]$.

TABle 1: ${ }^{31} \mathrm{P}\left\{{ }^{1} \mathrm{H}\right\}$ NMR shifts in ppm of the ligands and the synthesized precursor and catalyst complexes in $\mathrm{C}_{6} \mathrm{D}_{6}$.

\begin{tabular}{lccclc}
\hline \multicolumn{2}{c}{$P$-ligand } & \multicolumn{2}{c}{$\left[\mathrm{NiBrMes}\left(\mathrm{PR}^{\mathrm{a}} \mathrm{R}^{\mathrm{b}} \mathrm{R}^{\mathrm{c}}\right)_{2}\right]$} & \multicolumn{2}{c}{$\left[\mathrm{Ni}(\mathrm{L}) \mathrm{MesPR}^{\mathrm{a}} \mathrm{R}^{\mathrm{b}} \mathrm{R}^{\mathrm{c}}\right]$} \\
\hline $\mathrm{PPh}_{3}$ & -4.5 & 2b & $21.0[17]$ & $\mathbf{K} 2$ & $24.8[17]$ \\
$\mathrm{P}_{n} \mathrm{BuPh}_{2}$ & -14.8 & 3b & 14.5 & $\mathbf{K} 3$ & 18.9 \\
$\mathrm{P}_{n} \mathrm{Bu}_{2} \mathrm{Ph}$ & -23.1 & 4b & 6.5 & $\mathbf{K} 4$ & 11.9 \\
$\mathrm{P}_{n} \mathrm{Bu}_{3}$ & -29.6 & $\mathbf{5 b}$ & 3.5 & $\mathbf{K} 5$ & 10.4 \\
$\mathrm{P}(\mathrm{OEt})_{3}$ & 139.9 & $\mathbf{6 b}$ & 111.2 & $\mathbf{K} 6$ & 105.0 \\
$\mathrm{PCyPh}_{2}$ & -2.6 & 7b & 21.1 & $\mathbf{K} 7$ & 28.0 \\
\hline
\end{tabular}

TABle 2: Decomposition of the complexes during the catalysis experiments: GC/MS data.

\begin{tabular}{lccc}
\hline Complex & $\begin{array}{c}\text { Decomposition } \\
\text { product }\end{array}$ & $\begin{array}{c}\text { Retention } \\
\text { time/min }\end{array}$ & $m / z\left([\mathrm{M}]^{\bullet+}\right)$ \\
\hline K3 & $\mathrm{O}=\mathrm{P}_{n} \mathrm{BuPh}_{2}$ & 10.8 & 258 \\
K5 & $\mathrm{O}=\mathrm{P} n \mathrm{Bu}_{3}$ & 8.2 & 218 \\
K6 & $\mathrm{O}=\mathrm{P}(\mathrm{OEt})_{3}$ & 4.3 & 182 \\
\hline
\end{tabular}

The crystallographic data of the structures, interatomic distances, and bond angles are given in the Cambridge Crystallographic Data files CCDC-885214 (K5), CCDC885215 (K6), and CCDC-885216 (K7) (see Section 4 and Table 4).

2.2. Catalysis Experiments. The catalytic activity of the synthesized nickel complexes for the copolymerization of ethene and carbon monoxide was determined in a toluene solution at $60^{\circ} \mathrm{C}$ and 50 bar (CO partial pressure: 10 bar, $\mathrm{C}_{2} \mathrm{H}_{4}$ partial pressure: 40 bar) over 20 hours using a standard $100 \mathrm{~mL}$ stainless steel autoclave setup comprising a glass inlet. These

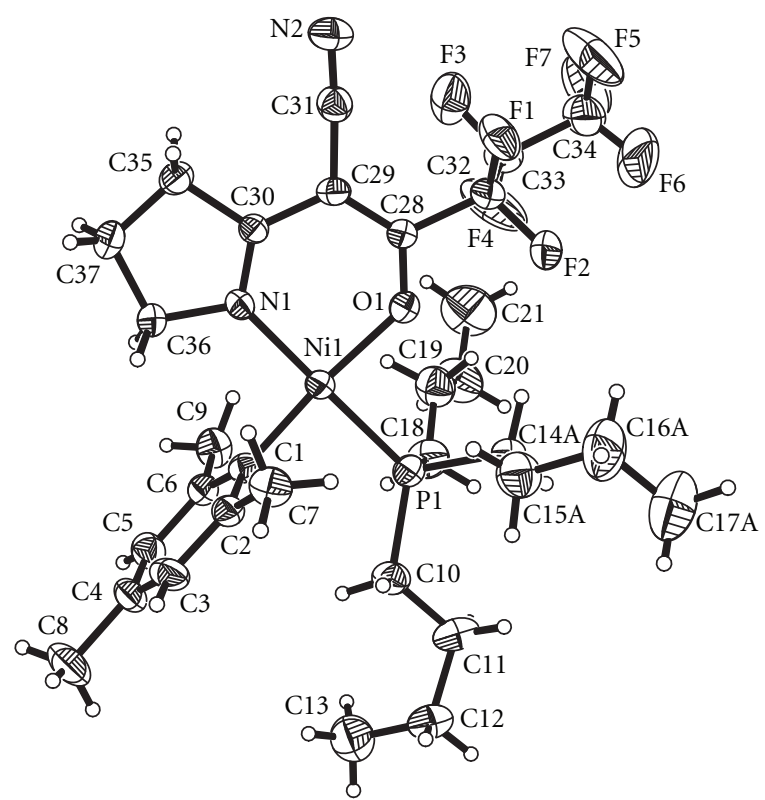

Figure 5: Diagram of complex K5 showing the atom-numbering scheme. Displacement ellipsoids are drawn at the $25 \%$ probability level. H-atom labels have been omitted for clarity. Only one orientation of the disordered butyl groups including atom C10 to $\mathrm{C} 13$ and $\mathrm{C} 14$ to $\mathrm{C} 17$ is shown.

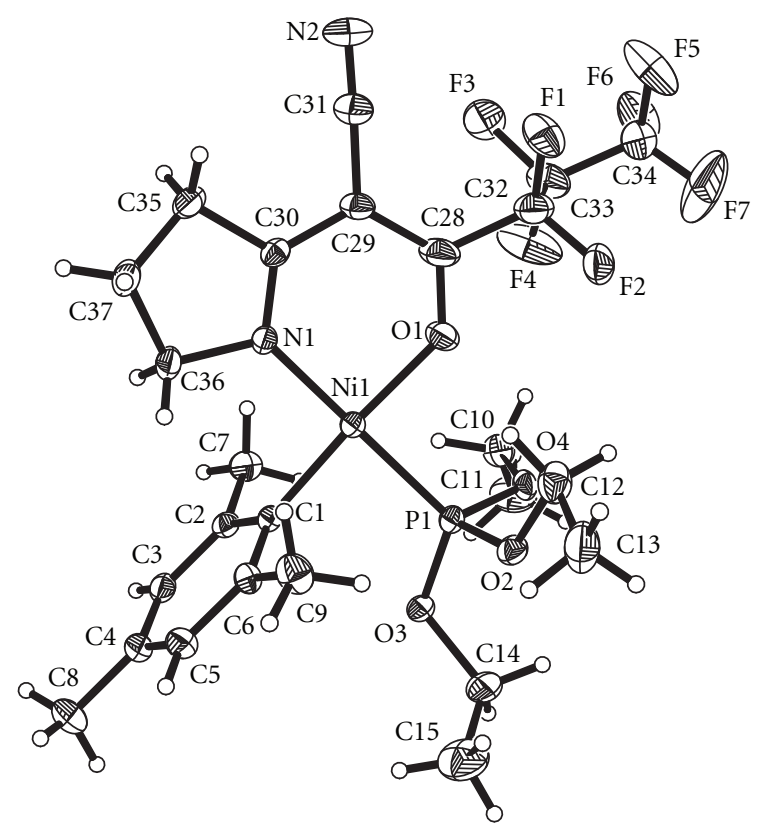

Figure 6: Diagram of complex K6: details are given in caption of Figure 5. Only one orientation of the disordered ethoxy groups is shown.

conditions were previously determined to give the highest polyketone yield with the catalyst K1 [15, 16]. Carbon monoxide on its own induces reduction to $\mathrm{Ni}(0)$; that is, it acts as catalyst poison. Therefore an excess of ethene is necessary.

While the efficiency of $\left[\mathrm{Ni}(\mathbf{L}) \mathrm{MesPPh}_{3}\right] \quad \mathbf{K} 2$ varies between 8,000 and $10,000 \mathrm{~g}$ polyketone perg nickel [19], 


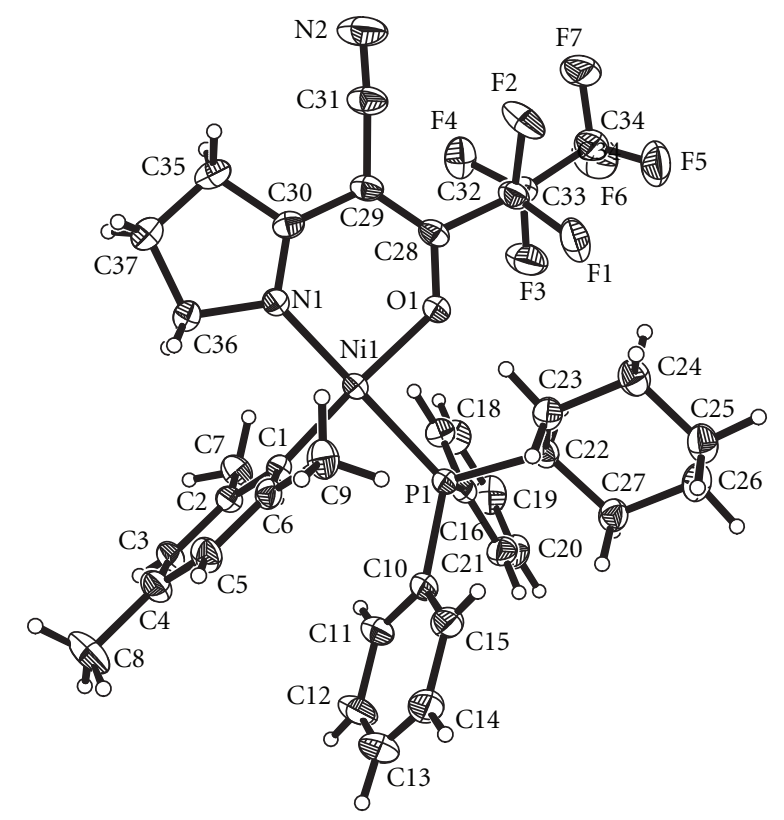

Figure 7: Diagram of complex K7: details are as given in caption of Figure 5.

the catalysis experiments with $\left[\mathrm{Ni}(\mathrm{L}) \mathrm{MesP}_{n} \mathrm{BuPh}_{2}\right] \quad \mathbf{K} 3$, $\left[\mathrm{Ni}(\mathrm{L}) \mathrm{MesP}_{n} \mathrm{Bu}_{3}\right] \mathbf{K} 5$, and $\left[\mathrm{Ni}(\mathrm{L}) \mathrm{MesP}(\mathrm{OEt})_{3}\right] \mathbf{K} \mathbf{6}$ showed interesting results as no (or only very little) formation of polyketone was observed. The overall efficiency of K3, K5, and $\mathbf{K} 6$ is zero. The toluene solution of the complexes after the catalysis experiments was colourless and cloudy, indicating decomposition of the complexes. The decomposition of the complexes was verified by GC/MS analysis of these solutions as here the oxidized $P$-ligand was detected in all cases (cf. Table 2).

No trace of the N,O-chelate ligand $\mathrm{HL}$ was found in the GC/MS spectra which shows that no undecomposed complex remained in the solution after the catalysis experiments. The $\mathrm{N}, \mathrm{O}$-chelate ligand forms the insoluble bis $(\mathrm{N}, \mathrm{O}$-chelate ligand) nickel complex $\left[\mathrm{NiL}_{2}\right]_{n}$ (Figure 8) which was detected in the IR spectra of the precipitate and previously determined as one of the decomposition products [28].

These independent investigations of the deactivation of the catalyst-carried out with the complexes $\mathbf{K} \mathbf{1}$ and K2-confirmed $\beta$-hydride elimination as one possibility for decomposition and always led to the bis $(\mathrm{N}, \mathrm{O}$-chelate ligand) nickel complex and the oxidized $P$-ligand as products [28] (triphenylphosphane oxide in the case of K1 and K2) thus the same decomposition products as in the case of K3, K5, and K6. Another decomposition pathway is the formation of nickel(0) carbonyl compounds such as $\left[\mathrm{Ni}(\mathrm{CO})_{3} \mathrm{PPh}_{3}\right]$ or $\left[\mathrm{Ni}(\mathrm{CO})_{2}\left(\mathrm{PPh}_{3}\right)_{2}\right]$ that were found when reacting complexes K1 and K2 with an excess of carbon monoxide [44]. A twofold insertion of carbon monoxide is thermodynamically not favoured [45] whereas a twofold insertion of ethene is kinetically too slow.

Another product detected in the GC/MS spectra of the solutions after the catalysis experiments was mesityl

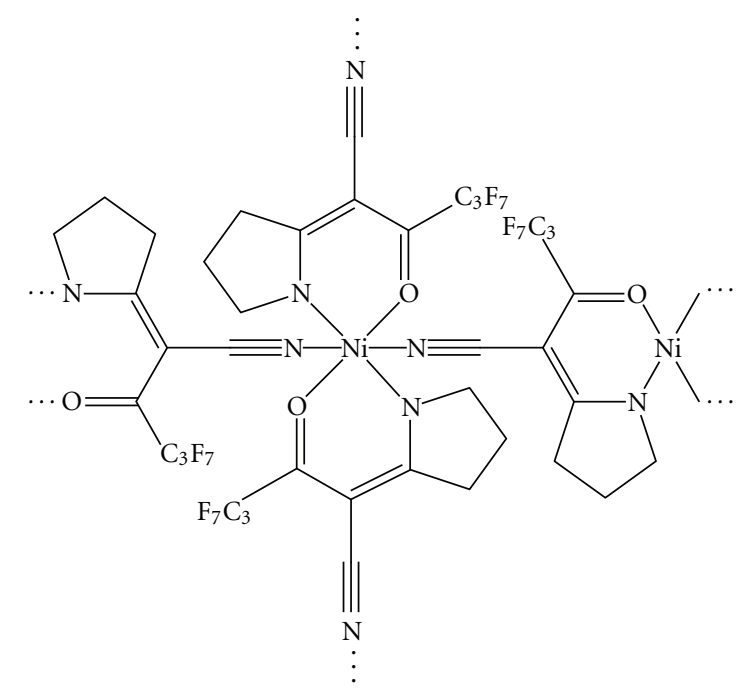

Figure 8: $\mathrm{Bis}\left(\mathrm{N}, \mathrm{O}\right.$-chelate ligand) nickel complex $\left[\mathrm{NiL}_{2}\right]_{n}[28]$.

TAble 3: Cone angles [12] and electronic parameters [12] of the $P$ ligands used here according to Tolman.

\begin{tabular}{lcc}
\hline$P$-ligand & ligand cone angle $\Theta /^{\circ}$ & Electronic parameter $\nu / \mathrm{cm}^{-1}$ \\
\hline $\mathrm{PPh}_{3}$ & 145 & 2068.9 \\
$\mathrm{P} n \mathrm{BuPh}_{2}$ & 141 & 2066.1 \\
$\mathrm{P}_{n} \mathrm{Bu}_{2} \mathrm{Ph}$ & 136 & 2063.2 \\
$\mathrm{P}_{n} \mathrm{Bu}_{3}$ & 132 & 2060.3 \\
$\mathrm{P}(\mathrm{OEt})_{3}$ & 109 & 2076.3 \\
$\mathrm{PCyPh}$ & 153 & 2064.8 \\
$\mathrm{PCy}$ & 170 & 2056.4 \\
$\mathrm{P}(\mathrm{o}-\mathrm{Tol})_{3}$ & 194 & 2066.6 \\
$\mathrm{P}(\mathrm{OPh})_{3}$ & 128 & 2085.3 \\
\hline
\end{tabular}

aldehyde. The presence of the mesityl aldehyde indicates the insertion of carbon monoxide into the nickel-carbon bond. Obviously the copolymerization reaction is not continued after the insertion of $\mathrm{CO}$ as no polyketone or oligomers of $\mathrm{CO} /$ ethene were found. Apparently the reaction rate of the decomposition is faster than the reaction rate for the insertion of ethene and carbon monoxide. Reasons for this are revealed by a closer look at the complexes K3, K5, and K6. All three complexes contain a $P$-ligand with a smaller cone angle than triphenylphosphane (Table 3 ). It can be concluded that complexes with both more basic as well as less basic $P$-ligands do not show catalytic activity, if the $P$-ligand has a smaller steric demand than triphenylphosphane.

The catalysis experiment with $\left[\mathrm{Ni}(\mathbf{L}) \mathrm{MesPCyPh}_{2}\right] \mathbf{K} 7$ yielded $3.4 \mathrm{~g}$ of polyketone, $\mathrm{K} 7$ thus shows an efficiency of $2,200 \mathrm{~g}$ polyketone per $\mathrm{g}$ nickel. The yielded polymer was investigated by IR spectroscopy showing the typical spectrum of a strictly alternating aliphatic polyketone including the valence vibrations of $\mathrm{C}=\mathrm{O}$ at $1695 \mathrm{~cm}^{-1}$ and of $\mathrm{C}-\mathrm{H}$ around $2910 \mathrm{~cm}^{-1}$, without any sign for the rocking band around $720 \mathrm{~cm}^{-1}$, characteristic for the presence of more than two of subsequent $\mathrm{CH}_{2}$ groups. The molecular weights of the 
TABLE 4: Crystallographic data for compounds K5, K6, and K7.

\begin{tabular}{|c|c|c|c|}
\hline Compound & K5 & K6 & K7 \\
\hline Formula & $\mathrm{C}_{31} \mathrm{H}_{44} \mathrm{~F}_{7} \mathrm{~N}_{2} \mathrm{NiOP}$ & $\mathrm{C}_{25} \mathrm{H}_{32} \mathrm{~F}_{7} \mathrm{~N}_{2} \mathrm{NiO}_{4} \mathrm{P}$ & $\mathrm{C}_{37} \mathrm{H}_{38} \mathrm{~F}_{7} \mathrm{~N}_{2} \mathrm{NiOP}$ \\
\hline$M$ & 683.34 & 647.19 & 749.35 \\
\hline Crystal system & Monoclinic & Triclinic & Triclinic \\
\hline Space group & $P 2_{1} / c$ & $P \overline{1}$ & $P \overline{1}$ \\
\hline$a / \AA$ & $12.0021(6)$ & $9.7103(7)$ & $9.9207(7)$ \\
\hline$b / \AA$ & $16.6042(11)$ & $11.7232(8)$ & $13.4244(11)$ \\
\hline$c / \AA$ & $18.4725(10)$ & $14.4679(11)$ & $14.4237(11)$ \\
\hline$\alpha l^{\circ}$ & 90 & $79.190(8)$ & $78.645(10)$ \\
\hline$\beta l^{\circ}$ & $104.344(6)$ & $76.418(8)$ & $74.442(9)$ \\
\hline$\gamma /^{\circ}$ & 90 & $69.264(8)$ & $78.768(9)$ \\
\hline$V / \AA^{3}$ & $3566.5(4)$ & $1487.3(2)$ & $1793.7(3)$ \\
\hline$Z$ & 4 & 2 & 2 \\
\hline$D_{c} / \mathrm{g} \mathrm{cm}^{-3}$ & 1.273 & 1.445 & 1.388 \\
\hline$F(000)$ & 1432 & 668 & 776 \\
\hline$\mu\left(\mathrm{Mo}-\mathrm{K}_{a}\right) / \mathrm{mm}^{-1}$ & 0.650 & 0.782 & 0.654 \\
\hline $2 \theta_{\max } l^{\circ}$ & 51.98 & 50.00 & 50.00 \\
\hline Total reflections & 24162 & 20560 & 24121 \\
\hline Independent reflections & 6949 & 4971 & 6128 \\
\hline Observed reflections $[I>2 s(I)]$ & 2801 & 3811 & 4084 \\
\hline Parameters refined & 448 & 394 & 445 \\
\hline$R 1 / w R 2[I>2 s(I)]$ & $0.0637,0.1223$ & $0.0622,0.1612$ & $0.0463,0.1022$ \\
\hline$R 1 / w R 2$ (all data) & $0.1238,0.1252$ & $0.0744,0.1644$ & $0.0661,0.1048$ \\
\hline Goodness-of-fit on $F^{2}$ & 1.201 & 1.746 & 1.100 \\
\hline Largest diff. peak and hole & $0.524 /-0.385$ & $1.276 /-0.542$ & $0.549 /-0.227$ \\
\hline
\end{tabular}

polymers produced were previously determined to be $>10^{5}$ [18].

Mechanistically two pathways are possible for the polymerization reaction, either an associative or a dissociative mechanism. In the case of an associative pathway the monomer would coordinate to the axial position of the square-planar nickel complex leading to a square-pyramidal species with a fivefold coordination which can then rearrange via Berry pseudorotation to a trigonal-bipyramidal intermediate which allows the coordinated monomer to insert into the nickel-carbon bond from a position cis to the arenido ligand. In the case of the dissociative pathway one of the coordinated ligands would have to dissociate first, either the $P$-ligand or the oxygen atom of the $\mathrm{N}, \mathrm{O}$-chelate ligand, forming an intermediate with a coordination number of three and a vacant coordination site where the monomer can bind to. It is unlikely that the $\mathrm{N}, \mathrm{O}$-chelate ligand acts as a hemilabile ligand as the ligand is fairly rigid and hemilability is unknown in anionic ligands. If the $O$-donor function of the $\mathrm{N}, \mathrm{O}$-chelate ligand would dissociate, the incoming monomer would coordinate trans to the arenido ligand and the complex would still have to isomerize to enable the insertion of the monomer into the nickel-carbon bond. Previous experiments with additional triphenylphosphane in the catalysis experiment have shown that free $\mathrm{PPh}_{3}$ has no influence on the catalytic activity [18] which indicates an associative pathway as free phosphane should slow down or inhibit a dissociative mechanism. Furthermore the addition of Lewis acids such as triphenylborane and $\mathrm{B}\left(\mathrm{C}_{6} \mathrm{~F}_{5}\right)_{3}$ which could act as phosphane scavengers does not have an effect on long-term catalytic runs as previously investigated [18]. Therefore an associative pathway for the coordination and insertion of the monomers seems likely which is also suggested by the trans-effect of the triphenylphosphane ligand and the nitrogen atom of the $\mathrm{N}, \mathrm{O}$ chelating ligand. The dissociation of the $P$-ligand rather leads to decomposition which could account for the inactivity of the complexes with less basic $P$-ligands.

Compared to K3, K5, and $\mathbf{K} \mathbf{6}$ the $P$-ligand of $\mathbf{K 7}$, cyclohexyldiphenylphosphane, has a higher steric demand (Table 3 ) and is more basic. Therefore a basic $P$-ligand with a relatively high steric demand seems to be important for a high catalytic activity of the complex.

The bulkiness of the $P$-ligand could support the insertion of the monomer into the nickel-carbon bond of the trigonalbipyramidal intermediate by creating steric pressure so that the insertion of the monomer would lead to steric relief.

The attempt to synthesize a complex containing a basic $P$-ligand with an increased cone angle failed so far. Experiments were carried out with tricyclohexylphosphane $\left(\mathrm{PCy}_{3}\right)$, tri-o-tolylphosphane $\left(\mathrm{P}(\mathrm{o}-\mathrm{Tol})_{3}\right)$, and triphenylphosphite $\left(\mathrm{P}(\mathrm{OPh})_{3}\right)$. In the case of $\mathrm{PCy}_{3}$ the Venanzi-type complex $\left[\mathrm{NiBr}_{2}\left(\mathrm{PCy}_{3}\right)_{2}\right]$ was synthesized, but it did not react with the Grignard reagent to form the mesitylenido complex $\left[\mathrm{NiBrMes}\left(\mathrm{PCy}_{3}\right)_{2}\right]$. The reaction of nickel dibromide with $\mathrm{P}(\mathrm{o}-\mathrm{Tol})_{3}$ did not yield the Venanzi-type complex which can be explained by the cone angle of $194^{\circ}$. The two phosphane 
ligands would sterically hinder one another at the nickel centre because the steric demand for two $\mathrm{P}(\mathrm{o}-\mathrm{Tol})_{3}$ ligands coordinating to nickel is too big. Furthermore the synthesis was tried with $\mathrm{P}(\mathrm{OPh})_{3}$, but here the Venanzi-type complex $\left[\mathrm{NiBr}_{2}\left(\mathrm{P}(\mathrm{OPh})_{3}\right)_{2}\right]$ proved to be not stable, not even under inert conditions.

\section{Conclusions}

In this work we presented an investigation on new nickel complexes as catalysts for the copolymerization of ethene and carbon monoxide starting from the complex $\left[\mathrm{Ni}(\mathrm{L}) \mathrm{MesPPh}_{3}\right]$ $\mathbf{K} \mathbf{2}$ which is an active catalyst for the synthesis of polyketones $[17,19]$. In the new complexes we altered the triphenylphosphane ligand to either more or less basic $P$-ligands and $P$ ligands with a higher or lower steric demand, K3, K4, K5, K6, and K7. Two pathways for the synthesis of the complexes were examined. The conventional approach to this type of complexes starting from nickel dibromide and the desired $P$-ligand can be replaced under certain conditions for a very straightforward synthesis in which triphenylphosphane in $\mathbf{K} 2$ is substituted by the desired P-ligand. This method works very well for $P$-ligands with less steric demand than triphenylphosphane which are more basic. The new complexes K3, K5, K6, and K7 were studied as catalysts for the copolymerization of ethene and carbon monoxide. Here the complexes containing a $P$-ligand with less steric demand than triphenylphosphane, $\mathbf{K} \mathbf{3}, \mathbf{K} \mathbf{5}$, and $\mathbf{K 6}$, regardless of the basicity, do not show catalytic activity, while the complex with cyclohexyldiphenylphosphane $\mathbf{K} 7$, thus a higher steric demand than $\mathrm{PPh}_{3}$, exhibits an overall efficiency of 2,200 g polyketone perg nickel. So far we can conclude that a minimum steric demand of the $P$-ligand is necessary for a high catalytic activity of the complex. Where the optimal basicity and steric demand lie is still open which is not surprising in view of the fact that the $P$-ligand influences both the insertion reactions of $\mathrm{CO}$ and ethene as well as the hydride elimination leading to catalyst decomposition.

\section{Experimental Section}

General Procedures and Syntheses. One-dimensional NMR spectra were recorded at room temperature, proton and ${ }^{31} \mathrm{P}$ NMR spectra on a Bruker Avance DRX 200 spectrometer. Additional $1 \mathrm{D}$ and $2 \mathrm{D}$ spectra were obtained for the nuclei ${ }^{1} \mathrm{H},{ }^{13} \mathrm{C},{ }^{31} \mathrm{P}$, and ${ }^{19} \mathrm{~F}$ by using a Bruker Avance DRX 500 spectrometer. The proton and carbon chemical shifts are given in $\mathrm{ppm}$ and referenced to the signal of residual solvent signals [46] $\left(\mathrm{CDCl}_{3}:{ }^{1} \mathrm{H} 7.26 \mathrm{ppm},{ }^{13} \mathrm{C} 77.16 \mathrm{ppm}\right.$; $\mathrm{CD}_{2} \mathrm{Cl}_{2}:{ }^{1} \mathrm{H} 5.30 \mathrm{ppm},{ }^{13} \mathrm{C} 53.52 \mathrm{ppm} ; \mathrm{C}_{6} \mathrm{D}_{6}:{ }^{1} \mathrm{H} 7.16 \mathrm{ppm}$, $\left.{ }^{13} \mathrm{C} 128.1 \mathrm{ppm}\right)$. Coupling constants are reported as absolute values and given in $\mathrm{Hz}$. Infrared spectra were recorded on an FT-IR Bruker IFS 66 spectrometer. EI-MS data and FAB-MS spectra were recorded on a Finnigan MAT 8200 in a 3-nitrobenzylalcohol matrix. Elemental analyses were performed by using a Perkin-Elmer CHN-2400/II elemental analyser. GC/MS spectra were determined on a Thermo Finnigan Trace GC-Ultra Trace DSQ comprising a column of
$15 \mathrm{~m}$ length with $0.25 \mathrm{~mm}$ in diameter and a DB5MS phase. Injection temperature was $220^{\circ} \mathrm{C}$, and column temperature increased starting at 50 up to $250^{\circ} \mathrm{C}$ with $20^{\circ} \mathrm{C} \mathrm{min}^{-1}$. The intensity of the signal in the gas chromatogram is listed as $\%$ area. Unless stated otherwise chemicals were purchased from commercial sources, used as received and dried and degassed by standard methods. The synthesis of the protonated $\mathrm{N}, \mathrm{O}$-chelate ligand 4,4,5,5,6,6,6-heptafluoro-3-oxo2-[pyrrolidin-(2Z)-ylidene] hexanenitrile (HL) was reported previously [27].

n-Butyldiphenylphosphane. The synthesis was carried out according to the literature [47] using chlorodiphenylphosphane $(3.7 \mathrm{~mL}, 20 \mathrm{mmol}$ ) and n-butyllithium (13.8 mL, 1.6 M solution in hexane). The reaction mixture was worked up as follows: after hydrolysis with half concentrated ammonia $(100 \mathrm{~mL})$, the organic layer was extracted with deionized water $(3 \times 50 \mathrm{~mL})$ and dried over $\mathrm{MgSO}_{4}$. The solvent was removed in vacuo yielding $4.6 \mathrm{~g}$ (95\%) of a colourless liquid. ${ }^{1} \mathrm{H}$ NMR $\left(200 \mathrm{MHz}, \mathrm{CDCl}_{3}\right): 0.89$ ( $\mathrm{t}, 3 \mathrm{H}$, $\mathrm{PCH}_{2} \mathrm{CH}_{2} \mathrm{CH}_{2} \mathrm{CH}_{3}$ ), 1.44 (mult, $4 \mathrm{H}, \mathrm{PCH}_{2} \mathrm{CH}_{2} \mathrm{CH}_{2} \mathrm{CH}_{3}$ ), 2.06 (t, 2H, $\mathrm{PCH}_{2} \mathrm{CH}_{2} \mathrm{CH}_{2} \mathrm{CH}_{3}$ ), 7.28 (mult, $6 \mathrm{H}, \mathrm{m}, \mathrm{p}-\mathrm{CH}$ $\mathrm{Ph}$ ), 7.43 (mult, 4H, o-CH Ph) ppm. ${ }^{1} \mathrm{H}$ NMR (200 MHz, $\mathrm{C}_{6} \mathrm{D}_{6}$ ): 0.77 ( $\mathrm{t}, 3 \mathrm{H}, \mathrm{PCH}_{2} \mathrm{CH}_{2} \mathrm{CH}_{2} \mathrm{CH}_{3}$ ), 1.32 (mult, $2 \mathrm{H}$, $\mathrm{PCH}_{2} \mathrm{CH}_{2} \mathrm{CH}_{2} \mathrm{CH}_{3}$ ), 1.41 (mult, $2 \mathrm{H}, \mathrm{PCH}_{2} \mathrm{CH}_{2} \mathrm{CH}_{2} \mathrm{CH}_{3}$ ), 1.95 (t, 2H, $\mathrm{PCH}_{2} \mathrm{CH}_{2} \mathrm{CH}_{2} \mathrm{CH}_{3}$ ), 7.10 (mult, $6 \mathrm{H}, \mathrm{m}, \mathrm{p}-\mathrm{CH}$ $\mathrm{Ph}), 7.43$ (mult, $4 \mathrm{H}, \mathrm{o}-\mathrm{CH} \mathrm{Ph}$ ) ppm. ${ }^{31} \mathrm{P}\left\{{ }^{1} \mathrm{H}\right\}$ NMR $(81 \mathrm{MHz}$, $\left.\mathrm{CDCl}_{3}\right): \delta=-14.8 \mathrm{ppm}$.

Di-n-butylphenylphosphane. The synthesis [47] was carried out as for n-butyldiphenylphosphane, except that dichlorophenylphosphane $(3.58 \mathrm{~g}, 20.0 \mathrm{mmol})$ and n-butyllithium (26.3 mL) were used. Yield: $4.0 \mathrm{~g}(90 \%) .{ }^{1} \mathrm{H} \mathrm{NMR}(200 \mathrm{MHz}$, $\mathrm{CDCl}_{3}$ ): 0.88 (t, 6H, $\mathrm{PCH}_{2} \mathrm{CH}_{2} \mathrm{CH}_{2} \mathrm{CH}_{3}$ ), 1.37 (mult, $8 \mathrm{H}$, $\mathrm{PCH}_{2} \mathrm{CH}_{2} \mathrm{CH}_{2} \mathrm{CH}_{3}$ ), 1.69 (mult, $4 \mathrm{H}, \mathrm{CH}_{2} \mathrm{CH}_{2} \mathrm{CH}_{2} \mathrm{CH}_{3}$ ), 7.35 (mult, 3H, m,p-CH Ph), 7.72 (mult, 2H, o-CH Ph) ppm. ${ }^{31} \mathrm{P}\left\{{ }^{1} \mathrm{H}\right\} \mathrm{NMR}\left(81 \mathrm{MHz}, \mathrm{CDCl}_{3}\right):-23.1 \mathrm{ppm}$.

Cyclohexyldiphenylphosphane. Chlorodiphenylphosphane $(3.05 \mathrm{~mL}, 17.0 \mathrm{mmol})$ was dissolved in tetrahydrofuran $(15 \mathrm{~mL})$. Cyclohexane magnesium bromide, prepared from $\mathrm{Mg}$ turnings $(0.56 \mathrm{~g}, 23 \mathrm{mmol})$ and bromocyclohexane $(3.75 \mathrm{~g}, 230 \mathrm{mmol})$ in tetrahydrofuran $(30 \mathrm{~mL})$, was added by means of a syringe and the reaction mixture stirred overnight. After hydrolysis with bidistilled water $(22 \mathrm{~mL})$ the solution was extracted with diethyl ether $(5 \times 50 \mathrm{~mL})$ and dried over $\mathrm{Na}_{2} \mathrm{SO}_{4}$. The solvent was removed in vacuo and the remaining white solid was dried yielding $4.4 \mathrm{~g}$ (96\%) of cyclohexyldiphenylphosphane. ${ }^{1} \mathrm{H}$ NMR $\left(200 \mathrm{MHz}, \mathrm{C}_{6} \mathrm{D}_{6}\right)$ : $\delta=1.16$ (mult, $6 \mathrm{H}, \mathrm{C} 3 \mathrm{H}_{2}$ and $\mathrm{C} 4 \mathrm{H}_{2} \mathrm{Cy}$ ), 1.60 (mult, $4 \mathrm{H}$,

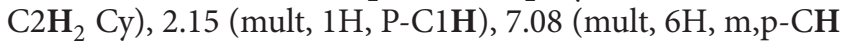
$\mathrm{Ph}), 7.55$ (mult, $4 \mathrm{H}, \mathrm{o}-\mathrm{CH} \mathrm{Ph}$ ) ppm. ${ }^{31} \mathrm{P}\left\{{ }^{1} \mathrm{H}\right\}$ NMR $(81 \mathrm{MHz}$, $\left.\mathrm{C}_{6} \mathrm{D}_{6}\right): \delta=-2.6 \mathrm{ppm}$.

General Procedure for the Synthesis of $\left[N i B r_{2}\left(P R^{a} R^{b} R^{c}\right)_{2}\right]$. Based on a modified literature procedure [39], anhydrous nickel dibromide $(1.64 \mathrm{~g}, 7.50 \mathrm{mmol})$ was dissolved in tetrahydrofuran $(70 \mathrm{~mL})$. The $P$-ligand $(15 \mathrm{mmol})$ was added and the reaction mixture heated to reflux for several hours. After removing the solvent, the remaining solid was dried in 
vacuo, but usually it was used directly for the reaction with the Grignard reagent.

$\left[\mathrm{NiBr}_{2}(\mathrm{PnBuPh})_{2}\right]$ (3a). Dark green solid. IR ( $\mathrm{KBr}$ disk): $\widetilde{v}=3072,3048(\nu \mathrm{C}-\mathrm{H}$ aromatic, $\mathrm{w}), 2959,2922,2872$, $2854(\nu \mathrm{C}-\mathrm{H}$ aliphatic, $\mathrm{m}), 1463,1433,1408,1380(\delta \mathrm{C}-\mathrm{H}$ aliphatic, s), $1098(v \mathrm{P}-\mathrm{C}, \mathrm{m}), 744,720(\delta \mathrm{C}-\mathrm{H}$ aromatic, s) $\mathrm{cm}^{-1}$. MS $(\mathrm{EI}): \mathrm{m} / z(\%)=242\left(\left[\mathrm{P}(n \mathrm{Bu}) \mathrm{Ph}_{2}\right]^{+}, 33\right), 200$ $\left(\left[\mathrm{PCH}_{3} \mathrm{Ph}_{2}\right]^{+}, 39\right), 199\left(\left[\mathrm{PCH}_{2} \mathrm{Ph}_{2}\right]^{+}, 91\right), 185\left(\left[\mathrm{PPh}_{2}\right]^{+}, 15\right)$, $183\left(\left[\mathrm{M}-\mathrm{C}_{20} \mathrm{H}_{30} \mathrm{PBr}_{2} \mathrm{Ni}\right]^{+}, 100\right), 152$ (17), 121 (22), 109 (40), $108\left([\mathrm{PPh}]^{+}, 54\right), 107(46), 77\left([\mathrm{Ph}]^{+}, 19\right), 57\left([n \mathrm{Bu}]^{+}, 8\right)$.

$\left[\mathrm{NiBr}_{2}\left(\mathrm{PnBu}_{2} \mathrm{Ph}\right)_{2}\right]$ (4a). Dark brown solid. IR ( $\mathrm{KBr}$ disk): $\widetilde{v}=3073,3056,3005(v \mathrm{C}-\mathrm{H}$ aromatic, $\mathrm{w}), 2956,2927,2867$ ( $v \mathrm{C}-\mathrm{H}$ aliphatic, vs), 1461, 1434, 1401, 1374 ( $\delta \mathrm{C}-\mathrm{H}$ aliphatic, s), $1092(v \mathrm{P}-\mathrm{C}, \mathrm{s}), 739,711(\delta \mathrm{C}-\mathrm{H}$ aromatic, $\mathrm{m}) \mathrm{cm}^{-1}$. MS (EI): $m / z(\%)=222\left(\left[\mathrm{P}(n \mathrm{Bu})_{2} \mathrm{Ph}\right]^{+}, 22\right), 193(21), 166$ $\left([\mathrm{HP}(n \mathrm{Bu}) \mathrm{Ph}]^{+}, 16\right), 138\left(\left[\mathrm{PC}_{2} \mathrm{H}_{6} \mathrm{Ph}\right]^{+}, 100\right), 109\left([\mathrm{HPPh}]^{+}\right.$, 63), $91(34), 77\left([\mathrm{Ph}]^{+}, 6\right), 57\left([n \mathrm{Bu}]^{+}, 5\right)$.

$\left[\mathrm{NiBr}_{2}\left(\mathrm{PnBu}_{3}\right)_{2}\right](\mathbf{5 a})$. Dark purple solid. ${ }^{1} \mathrm{H}$ NMR $\left(200 \mathrm{MHz}, \mathrm{CDCl}_{3}\right): \delta=0.95\left(\mathrm{t}, 18 \mathrm{H}, \mathrm{CH}_{2} \mathrm{CH}_{2} \mathrm{CH}_{2} \mathrm{CH}_{3}\right)$, $1.50\left(\mathrm{~m}, 12 \mathrm{H}, \quad \mathrm{CH}_{2} \mathrm{CH}_{2} \mathrm{CH}_{2} \mathrm{CH}_{3}\right), \quad 1.66(\mathrm{~m}, 12 \mathrm{H}$, $\left.\mathrm{CH}_{2} \mathrm{CH}_{2} \mathrm{CH}_{2} \mathrm{CH}_{3}\right), 1.90\left(\mathrm{~m}, 12 \mathrm{H}, \mathrm{CH}_{2} \mathrm{CH}_{2} \mathrm{CH}_{2} \mathrm{CH}_{3}\right) \mathrm{ppm}$. IR ( $\mathrm{KBr}$ disk): $\widetilde{v}=2958,2927,2869(v \mathrm{C}-\mathrm{H}$ aliphatic, s), $1463,1412,1378(\delta \mathrm{C}-\mathrm{H}$ aliphatic, $\mathrm{m}), 800(v \mathrm{P}-\mathrm{C}$, vs) $\mathrm{cm}^{-1}$. MS (ESI): $\mathrm{m} / z(\%)=543\left([\mathrm{M}-\mathrm{Br}]^{+}, 6 \%\right), 340$ $\left(\left[\mathrm{M}-\mathrm{Br}-\mathrm{P}(n \mathrm{Bu})_{3}\right]^{+}, \quad 2\right), \quad 283\left(\left[\mathrm{M}-\mathrm{C}_{16} \mathrm{H}_{36} \mathrm{PBr}\right]^{+}, 13\right), 227$ $\left(\left[\mathrm{M}-\mathrm{C}_{20} \mathrm{H}_{45} \mathrm{PBr}\right]^{+}, 4\right), 203\left(\left[\mathrm{HP}(n \mathrm{Bu})_{3}\right]^{+}, 100\right), 147([\mathrm{M}-$ $\left.\left.\mathrm{C}_{20} \mathrm{H}_{45} \mathrm{PBr}_{2}\right]^{+}, 13\right)$. MS (EI): $m / z(\%)=283\left(\left[{ }^{81} \mathrm{Br}-\mathrm{P}(n \mathrm{Bu})_{3}\right]^{+}\right.$, 11), $281\left(\left[{ }^{79} \mathrm{Br}-\mathrm{P}(n \mathrm{Bu})_{3}\right]^{+}, 11\right), 202\left(\left[\mathrm{P}(n \mathrm{Bu})_{3}\right]^{+}, 7\right), 173$ ([M-C $\left.\left.{ }_{14} \mathrm{H}_{32} \mathrm{PBr}_{2}\right]^{+}, 18\right), 131$ (13), 118 (20), 104 (23), 89 $\left([\mathrm{HP}(n \mathrm{Bu})]^{+}, 16\right), 76\left(\left[\mathrm{PC}_{3} \mathrm{H}_{9}\right]^{+}, 100\right), 62\left(\left[\mathrm{PC}_{2} \mathrm{H}_{7}\right]^{+}, 59\right), 61$ $\left(\left[\mathrm{PC}_{2} \mathrm{H}_{6}\right]^{+}, 46\right), 57\left([n \mathrm{Bu}]^{+}, 11\right)$.

$\left[\mathrm{NiBr}_{2}\left(\mathrm{P}(\mathrm{OEt})_{3}\right)_{2}\right](\mathbf{6 a})$. Dark purple solid. ${ }^{1} \mathrm{H}$ NMR $\left(200 \mathrm{MHz} \mathrm{CDCl}_{3}\right.$ ): 1.43 (mult, $18 \mathrm{H}, \mathrm{CH}_{3}$ ), 4.36 (mult, $12 \mathrm{H}$, $\left.\mathrm{CH}_{2}\right)$ ppm. IR ( $\mathrm{KBr}$ disk): $\widetilde{v}=2983,2931,2906(\nu \mathrm{C}-\mathrm{H}$ aliphatic, $\mathrm{m}), 1477,1442,1392(\delta \mathrm{C}-\mathrm{H}$ aliphatic, $\mathrm{m}), 1025$, 783 ( $v$ P-O-C, vs) $\mathrm{cm}^{-1}$. MS (MALDI): $m / z(\%)=507,509$, $511\left(\left[\mathrm{M}-\mathrm{C}_{2} \mathrm{HO}\right]^{+}\right.$, isotope pattern of ${ }^{58} \mathrm{Ni},{ }^{60} \mathrm{Ni},{ }^{79} \mathrm{Br}$ and ${ }^{81} \mathrm{Br}$ clearly identifiable), $391\left(\left[\mathrm{M}-\mathrm{Br}_{2}\right]^{+}\right)$.

$\left[\mathrm{NiBr}_{2}\left(\mathrm{PC} y \mathrm{Ph}_{2}\right)_{2}\right](\mathbf{7 a})$. This compound was synthesized according to the general procedure described above, except that $\mathrm{PCyPh}_{2}$ was dissolved before adding it to the $\mathrm{NiBr}_{2}$ solution. The complex can be isolated as a dark green solid. IR ( $\mathrm{KBr}$ disk): $\widetilde{v}=3052(\nu \mathrm{C}-\mathrm{H}$ aromatic, $\mathrm{w}), 2926,2851(\nu \mathrm{C}-\mathrm{H}$ aliphatic, vs), 1436, 1384 ( $\delta \mathrm{C}-\mathrm{H}$ aliphatic, s), 1096 ( $v \mathrm{P}-\mathrm{C}, \mathrm{m})$, 737, 723 ( $\delta \mathrm{C}-\mathrm{H}$ aromatic, $\mathrm{s}) \mathrm{cm}^{-1}$.

$\left[\mathrm{NiBr}_{2}\left(\mathrm{PC} y_{3}\right)_{2}\right](\mathbf{8 a})$. This compound was synthesized according to the general procedure described above, except that the synthesis was carried out in ethanol and $\mathrm{PCy}_{3}$ was dissolved before adding it to the $\mathrm{NiBr}_{2}$ solution. Upon refluxing the product precipitated, the brown solid was stirred in diethylether. IR ( $\mathrm{KBr}$ disk): $\widetilde{v}=2925,2845$ ( $v \mathrm{C}-\mathrm{H}$ aliphatic, vs), 1442 ( $\delta \mathrm{C}-\mathrm{H}$ aliphatic, $\mathrm{m}), 731$ ( $v \mathrm{P}-\mathrm{C}$, m) $\mathrm{cm}^{-1}$. MS (ESI, thf): $\mathrm{m} / z(\%)=668,669,670,671$ $\left(\left[\mathrm{M}-\mathrm{C}_{8} \mathrm{H}_{14}\right]^{+}, 21\right.$, isotope pattern of ${ }^{58} \mathrm{Ni},{ }^{60} \mathrm{Ni},{ }^{79} \mathrm{Br}$ and ${ }^{81} \mathrm{Br}$ clearly identifiable), 500, $502\left(\left[\mathrm{M}-\mathrm{C}_{6} \mathrm{H}_{15} \mathrm{PBr}_{2}\right]^{+}, 100\right.$, isotope pattern of ${ }^{58} \mathrm{Ni}$ and ${ }^{60} \mathrm{Ni}$ clearly identifiable). MS (MALDI): $m / z(\%)=505,507\left(\left[\mathrm{M}-\mathrm{C}_{6} \mathrm{H}_{11} \mathrm{PBr}_{2}\right]^{+}\right.$, isotope pattern of ${ }^{58} \mathrm{Ni}$ and $\left.{ }^{60} \mathrm{Ni}\right), 281\left(\left[\mathrm{HPCy}_{3}\right]^{+}\right) . \mathrm{C}_{36} \mathrm{H}_{66} \mathrm{P}_{2} \mathrm{Br}_{2} \mathrm{Ni}$ (779.37): calcd. C 55.48, H 8.55; found C 55.6, H 8.6.

$\left[\mathrm{NiBr}_{2}\left(\mathrm{P}(\mathrm{OPh})_{3}\right)_{2}\right]$ (9a). Red-brown gel-like solid. Letting the reaction solution stand for several weeks leads to very few red-brown crystals which were analysed by IR spectroscopy. IR ( $\mathrm{KBr}$ plates, paraffin oil): $\widetilde{v}=1619(\nu \mathrm{C}-\mathrm{C}$ aromatic, w), $1237(v \mathrm{C}-\mathrm{O}, \mathrm{w}), 873(v \mathrm{P}-\mathrm{O}, \mathrm{m}), 724(\delta \mathrm{C}-\mathrm{H}$ aromatic, w) $\mathrm{cm}^{-1}$.

[NiBrMes $\left.(\mathrm{PnBuPh})_{2}\right]$ (3b). Anhydrous nickel dibromide $(1.64 \mathrm{~g}, 7.50 \mathrm{mmol})$ was dissolved in tetrahydrofuran (70 mL). n-Butyldiphenylphosphane $(3.6 \mathrm{~g}, 15 \mathrm{mmol})$ was added and the reaction mixture was heated to reflux for two to three hours. Upon cooling to room temperature, mesitylenido magnesium bromide, prepared from $\mathrm{Mg}$ $(0.24 \mathrm{~g}, 10 \mathrm{mmol})$ and 2-bromomesitylene $(2.0 \mathrm{~g}, 10 \mathrm{mmol})$ in tetrahydrofuran $(20 \mathrm{~mL})$, was added by means of a syringe. After stirring over night at room temperature, the solvent was removed in vacuo and the mixture quenched with methanol $(100 \mathrm{~mL})$. After removing the methanol in vacuo, the solid was treated with dichloromethane, filtered and the solvent again removed in vacuo yielding $0.58 \mathrm{~g}(40 \%)$ of a brown solid. ${ }^{1} \mathrm{H}$ NMR $\left(200 \mathrm{MHz}, \mathrm{CDCl}_{3}\right): \delta=0.68(\mathrm{t}$, $\left.6 \mathrm{H}, \mathrm{CH}_{3} \mathrm{Bu}\right), 0.88-1.12\left(\mathrm{~m}, 12 \mathrm{H}, \mathrm{CH}_{2} \mathrm{Bu}\right), 1.98(\mathrm{~s}, 3 \mathrm{H}$, p- $\mathrm{CH}_{3} \mathrm{Mes}$ ), 2.48 (s, 6H, o- $\mathrm{CH}_{3} \mathrm{Mes}$ ), 6.09 (s, 2H, CH Mes), $\left.7.21(\mathrm{~m}, 12 \mathrm{H}, \mathrm{CH} \mathrm{Ph}), 7.55(\mathrm{~m}, 8 \mathrm{H}, \mathrm{CH} \mathrm{Ph}) \mathrm{ppm} .{ }^{13} \mathrm{C}^{1}{ }^{1} \mathrm{H}\right\}$ NMR $\left(126 \mathrm{MHz}, \mathrm{C}_{6} \mathrm{D}_{6}\right): \delta=14.0\left(\mathrm{PCH}_{2} \mathrm{CH}_{2} \mathrm{CH}_{2} \mathrm{CH}_{3}\right)$, 20.8 (p- $\left.\mathrm{CH}_{3} \mathrm{Mes}\right), 25.0\left(\mathrm{PCH}_{2} \mathrm{CH}_{2} \mathrm{CH}_{2} \mathrm{CH}_{3}\right), 26.8\left(\mathrm{o}-\mathrm{CH}_{3}\right.$ Mes), $27.6\left(\mathrm{PCH}_{2} \mathrm{CH}_{2} \mathrm{CH}_{2} \mathrm{CH}_{3}\right), 27.8\left(\mathrm{PCH}_{2} \mathrm{CH}_{2} \mathrm{CH}_{2} \mathrm{CH}_{3}\right)$, 127.4 (CH Mes), $129.8\left(\mathrm{~m}-\mathrm{CH} \mathrm{PPh}_{2}\right), 131.7\left(\mathrm{p}-\mathrm{CH} \mathrm{PPh}_{2}\right)$, 132.8 (p-C Mes), 134.1 (i-C $\mathrm{PPh}_{2}$ ), 134.7 (o-CH PPh 2 ), 142.6 $\left(\mathrm{d},{ }^{3} \mathrm{~J}_{C P}=3.9 \mathrm{~Hz}\right.$, o-C Mes $), 146.3\left(\mathrm{~d},{ }^{2} \mathrm{~J}_{C P}=32.8 \mathrm{~Hz}\right.$, i-C Mes) ppm. ${ }^{31} \mathrm{P}\left\{{ }^{1} \mathrm{H}\right\} \operatorname{NMR}\left(81 \mathrm{MHz}, \mathrm{CDCl}_{3}\right): \delta=14.1 \mathrm{ppm}$. ${ }^{31} \mathrm{P}\left\{{ }^{1} \mathrm{H}\right\} \operatorname{NMR}\left(81 \mathrm{MHz}, \mathrm{C}_{6} \mathrm{D}_{6}\right): \delta=14.5 \mathrm{ppm}$. IR (KBr disk): $\widetilde{v}=3051,3003(\nu \mathrm{C}-\mathrm{H}$ aromatic, $\mathrm{w}), 2955,2928,2869(\nu \mathrm{C}-\mathrm{H}$ aliphatic, m), 1459, 1433, 1376, 1307 ( $\delta \mathrm{C}-\mathrm{H}$ aliphatic, s), $800(\nu \mathrm{P}-\mathrm{C}, \mathrm{w}), 742,713\left(\delta \mathrm{C}-\mathrm{H}\right.$ aromatic, vs $\mathrm{cm}^{-1}$. MS (MALDI): $m / z(\%)=461,361\left(\left[\mathrm{Mes}-\mathrm{P}(n \mathrm{Bu}) \mathrm{Ph}_{2}\right]^{+}, 100 \%\right)$, 340 . This compound was used without further purification.

$\left[\mathrm{NiBrMes}\left(\mathrm{PnBu}_{2} \mathrm{Ph}\right)_{2}\right](\mathbf{4 b})$. The synthesis was carried out as for $\mathbf{3 b}$, except that di-n-butylphenylphosphane $(3.3 \mathrm{~g}$, $15 \mathrm{mmol}$ ) was used. Yield: $1.4 \mathrm{~g}(27 \%) .{ }^{1} \mathrm{H}$ NMR $(200 \mathrm{MHz}$, $\left.\mathrm{CDCl}_{3}\right): \delta=0.79\left(\mathrm{t}, 12 \mathrm{H}, \mathrm{CH}_{3} \mathrm{Bu}\right), 1.24-1.49(\mathrm{~m}$, $24 \mathrm{H}, \mathrm{CH}_{2} \mathrm{Bu}$ ), 2.08 (s, 3H, p-CH $\mathrm{CH}_{3} \mathrm{Mes}$ ), 2.46 (s, 6H, o$\left.\mathrm{CH}_{3} \mathrm{Mes}\right), 6.29$ (s, 2H, CH Mes), $7.22(\mathrm{~m}, 6 \mathrm{H}, \mathrm{CH} \mathrm{Ph})$, $7.32(\mathrm{~m}, 4 \mathrm{H}, \mathrm{CH} \mathrm{Ph}) \mathrm{ppm} .{ }^{13} \mathrm{C}\left\{{ }^{1} \mathrm{H}\right\}$ NMR $(126 \mathrm{MHz}$, $\left.\mathrm{C}_{6} \mathrm{D}_{6}\right): \delta=14.1\left(\mathrm{PCH}_{2} \mathrm{CH}_{2} \mathrm{CH}_{2} \mathrm{CH}_{3}\right), 21.0$ (p- $\left.\mathrm{CH}_{3} \mathrm{Mes}\right)$, $24.0\left(\mathrm{PCH}_{2} \mathrm{CH}_{2} \mathrm{CH}_{2} \mathrm{CH}_{3}\right), 25.1\left(\mathrm{PCH}_{2} \mathrm{CH}_{2} \mathrm{CH}_{2} \mathrm{CH}_{3}\right), 26.6$ (o- $\mathrm{CH}_{3} \mathrm{Mes}$ ), 26.9 ( $\mathrm{PCH}_{2} \mathrm{CH}_{2} \mathrm{CH}_{2} \mathrm{CH}_{3}$ ), 127.1 (CH Mes), 129.3 (m-CH PPh), 132.1 (p-C Mes), 132.4 (o-CH PPh), 132.8 (p-CH PPh), 134.0 (i-C PPh), $142.7\left(\mathrm{t}^{3}{ }^{3} \mathrm{~J}_{\mathrm{CP}}=3.9 \mathrm{~Hz}, \mathrm{o}^{-}\right.$ C Mes), $146.0\left(\mathrm{t},{ }^{2} \mathrm{~J}_{C P}=32.8 \mathrm{~Hz}, \mathrm{i}-\mathrm{C}\right.$ Mes) ppm. ${ }^{31} \mathrm{P}\left\{{ }^{1} \mathrm{H}\right\} \mathrm{NMR}$ $\left(81 \mathrm{MHz}, \mathrm{CDCl}_{3}\right): \delta=5.7 \mathrm{ppm} .{ }^{31} \mathrm{P}\left\{{ }^{1} \mathrm{H}\right\} \operatorname{NMR}(81 \mathrm{MHz}$, $\left.\mathrm{C}_{6} \mathrm{D}_{6}\right): \delta=6.5 \mathrm{ppm}$. IR (KBr disk): $\widetilde{v}=3077,3054(\nu \mathrm{C}-\mathrm{H}$ 
aromatic, w), 2956, 2928, 2870 ( $\nu \mathrm{C}-\mathrm{H}$ aliphatic, vs), 1461, 1434, 1379, 1342, 1303 ( $v \mathrm{C}-\mathrm{H}$ aliphatic, s), 799 ( $\nu \mathrm{P}-\mathrm{C}, \mathrm{w})$, 740,711 ( $\delta \mathrm{C}-\mathrm{H}$ aromatic, vs) $\mathrm{cm}^{-1}$. MS (MALDI): $\mathrm{m} / z(\%)=$ $701\left([\mathrm{M}]^{+}\right), 621\left([\mathrm{M}-\mathrm{Br}]^{+}\right), 566\left([\mathrm{M}-(n \mathrm{Bu})-\mathrm{Ph}]^{+}\right), 510([\mathrm{M}-$ $\left.2(n \mathrm{Bu})-\mathrm{Ph}]^{+}\right), 490\left([\mathrm{M}-(n \mathrm{Bu})-2 \mathrm{Ph}]^{+}\right), 431([\mathrm{M}-\mathrm{Br}-2(n \mathrm{Bu})-$ $\left.\mathrm{Ph}]^{+}\right), 400\left(\left[\mathrm{M}-\mathrm{Br}-\mathrm{P}(n \mathrm{Bu})_{2} \mathrm{Ph}\right]^{+}\right), 341\left(\left[\text { Mes- } \mathrm{P}(n \mathrm{Bu})_{2} \mathrm{Ph}\right]^{+}\right.$, $100 \%)$. This compound was used without further purification.

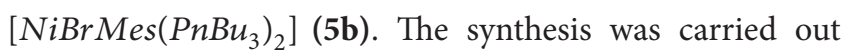
as for $\mathbf{3 b}$, except that tri-n-butylphenylphosphane $(3.0 \mathrm{~g}$, $15 \mathrm{mmol})$ was used. Yield: $3.6 \mathrm{~g}(72 \%) .{ }^{1} \mathrm{H}$ NMR $(200 \mathrm{MHz}$, $\left.\mathrm{CDCl}_{3}\right): \delta=0.81\left(\mathrm{t}, 18 \mathrm{H}, \mathrm{CH}_{3} \mathrm{Bu}\right), 1.20-1.40(\mathrm{~m}, 36 \mathrm{H}$, $\mathrm{CH}_{2} \mathrm{Bu}$ ), 2.10 (s, 3H, p- $\mathrm{CH}_{3} \mathrm{Mes}$ ), 2.82 (s, 6H, o- $\mathrm{CH}_{3}$ Mes), 6.41 (s, 2H, CH Mes) ppm. ${ }^{13} \mathrm{C}\left\{{ }^{1} \mathrm{H}\right\}$ NMR $(126 \mathrm{MHz}$, $\left.\mathrm{C}_{6} \mathrm{D}_{6}\right): \delta=14.2\left(\mathrm{PCH}_{2} \mathrm{CH}_{2} \mathrm{CH}_{2} \mathrm{CH}_{3}\right), 21.0$ (p- $\left.\mathrm{CH}_{3} \mathrm{Mes}\right)$, $24.8\left(\mathrm{PCH}_{2} \mathrm{CH}_{2} \mathrm{CH}_{2} \mathrm{CH}_{3}\right), 25.5\left(\mathrm{PCH}_{2} \mathrm{CH}_{2} \mathrm{CH}_{2} \mathrm{CH}_{3}\right), 27.0$ (o- $\mathrm{CH}_{3} \mathrm{Mes}$ ), $27.2\left(\mathrm{PCH}_{2} \mathrm{CH}_{2} \mathrm{CH}_{2} \mathrm{CH}_{3}\right), 126.7$ (CH Mes), 132.6 (p-C Mes), 142.2 (t, ${ }^{3} \mathrm{~J}_{\mathrm{CP}}=3.9 \mathrm{~Hz}$, o-C Mes), 147.1 $\left(\mathrm{t},{ }^{2} \mathrm{~J}_{C P}=32.8 \mathrm{~Hz}\right.$, i-C Mes) ppm. ${ }^{31} \mathrm{P}\left\{{ }^{1} \mathrm{H}\right\} \operatorname{NMR}(81 \mathrm{MHz}$, $\left.\mathrm{CDCl}_{3}\right): \delta=2.6 \mathrm{ppm} .{ }^{31} \mathrm{P}\left\{{ }^{1} \mathrm{H}\right\} \operatorname{NMR}\left(81 \mathrm{MHz}, \mathrm{C}_{6} \mathrm{D}_{6}\right): \delta$ $=3.5$ ppm. IR (KBr disk): $\widetilde{v}=2956,2927,2869(\nu \mathrm{C}-\mathrm{H}$ aliphatic, vs), 1463, 1377, 1341, $1300(\delta \mathrm{C}-\mathrm{H}$ aliphatic, s), $796(v \mathrm{P}-\mathrm{C}, \mathrm{m}) \mathrm{cm}^{-1}$. MS (EI): $m / z(\%)=322(35), 321$ $\left(\left[\mathrm{Mes}-\mathrm{P}(n \mathrm{Bu})_{3}\right]^{+}, 100\right), 202\left(\left[\mathrm{P}(n \mathrm{Bu})_{3}\right]^{+}, 13\right), 173(20), 119$ $\left([\mathrm{Mes}]^{+}, 11\right), 104(28), 89\left([\mathrm{HP}(n \mathrm{Bu})]^{+}, 14\right), 76(88), 57$ $\left([n \mathrm{Bu}]^{+}, 10\right)$. MS (MALDI): $m / z(\%)=490\left(\left[\mathrm{M}-\mathrm{C}_{12} \mathrm{H}_{27}\right]^{+}\right)$, $485\left([\mathrm{M}-\mathrm{Mes}-(n \mathrm{Bu})]^{+}\right), 321\left(\left[\mathrm{Mes}-\mathrm{P}(n \mathrm{Bu})_{3}\right]^{+}, 100 \%\right)$. This compound was used without further purification.

[NiBrMes $\left.\left(\mathrm{P}(\mathrm{OEt})_{3}\right)_{2}\right]$ (6b). Triethylphosphite (3.32 g, $20.0 \mathrm{mmol}$ ) was added to anhydrous nickel dibromide $(2.19 \mathrm{~g}, 10.0 \mathrm{mmol})$, whereupon the dark violet complex $\mathbf{6 a}$ directly forms. The reaction mixture was dissolved in tetrahydrofuran and heated to reflux for several hours. Upon cooling to room temperature, mesitylenido magnesium bromide, prepared from $\mathrm{Mg}(0.24 \mathrm{~g}, 10 \mathrm{mmol})$ and 2-bromomesitylene $(2.0 \mathrm{~g}, 10 \mathrm{mmol})$ in tetrahydrofuran $(20 \mathrm{~mL})$, was added by means of a syringe. After stirring over night at room temperature, the solvent was removed in vacuo and the mixture quenched with methanol $(50 \mathrm{~mL})$. Undissolved solid was filtered off and the solvent removed in vacuo. The remaining solid was dissolved in toluene $(100 \mathrm{~mL})$ and again undissolved solid was filtered off. After removing the toluene in vacuo the orange solid was recrystallized from methanol. Orange needle-like crystals were obtained at $-6^{\circ} \mathrm{C}$ yielding $3.7 \mathrm{~g}(62 \%)$. ${ }^{1} \mathrm{H}$ NMR $\left(200 \mathrm{MHz}, \mathrm{C}_{6} \mathrm{D}_{6}\right): \delta=1.03$ (t, $18 \mathrm{H}, \mathrm{OCH}_{2} \mathrm{CH}_{3}$ ), 2.27 (s, 3H, p-CH 3 Mes), 3.11 (s, 6H, o- $\mathrm{CH}_{3} \mathrm{Mes}$ ), 4.04 (mult, $12 \mathrm{H}, \mathrm{OCH}_{2} \mathrm{CH}_{3}$ ), 6.69 (s, $2 \mathrm{H}$, CH Mes) ppm. ${ }^{13} \mathrm{C}\left\{{ }^{1} \mathrm{H}\right\}$ NMR (126 MHz, $\left.\mathrm{C}_{6} \mathrm{D}_{6}\right): \delta=16.7$ $\left(\mathrm{OCH}_{2} \mathbf{C H}_{3}\right.$ ), 21.1 (p- $\mathrm{CH}_{3} \mathrm{Mes}$ ), 26.2 (o- $\left.\mathrm{CH}_{3} \mathrm{Mes}\right), 62.1$ $\left(\mathrm{OCH}_{2} \mathrm{CH}_{3}\right.$ ), 126.6 (CH Mes), 132.6 (p-C Mes), 143.5 (o-C Mes) ppm. ${ }^{31} \mathrm{P}\left\{{ }^{1} \mathrm{H}\right\} \operatorname{NMR}\left(81 \mathrm{MHz}, \mathrm{C}_{6} \mathrm{D}_{6}\right): \delta=111.2 \mathrm{ppm}$. IR (KBr disk): $\widetilde{v}=2980,2929,2901(\nu \mathrm{C}-\mathrm{H}$ aliphatic, $\mathrm{m}), 1475,1442,1388$ ( $\delta \mathrm{C}-\mathrm{H}$ aliphatic, w), 1031, 780, 740 $(v \mathrm{P}-\mathrm{O}-\mathrm{C}, \mathrm{vs}) \mathrm{cm}^{-1}$. MS (ESI, $\left.\mathrm{CH}_{3} \mathrm{OH} / \mathrm{HCOOH}\right): \mathrm{m} / z(\%)=$ 285 ([Mes-P(OEt) $\left.\left.]_{3}\right]^{+}, 6 \%\right), 214(23), 201$ (100), 183 (47), 166

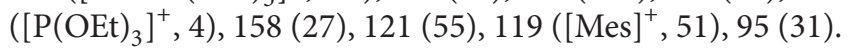

$\mathrm{C}_{21} \mathrm{H}_{41} \mathrm{BrO}_{6} \mathrm{P}_{2} \mathrm{Ni}$ (590.21): calcd. C 42.73, $\mathrm{H}$ 7.02; found $\mathrm{C}$ 42.5, $\mathrm{H} 7.0$.

[NiBrMes $\left.\left(\mathrm{PC} y \mathrm{Ph}_{2}\right)_{2}\right]$ (7b). Anhydrous nickel dibromide $(1.10 \mathrm{~g}, 5.00 \mathrm{mmol})$ was dissolved in ethanol $(100 \mathrm{~mL})$. In a separate flask cyclohexyldiphenylphosphane $(2.72 \mathrm{~g}$, $10.1 \mathrm{mmol})$ was dissolved in ethanol $(80 \mathrm{~mL})$, this solution was added to the first solution by means of a syringe, and the reaction mixture was heated to reflux for 40 minutes. Upon cooling to room temperature, mesitylenido magnesium bromide, prepared from $\mathrm{Mg}(0.24 \mathrm{~g}, 10 \mathrm{mmol})$ and 2-bromomesitylene $(2.0 \mathrm{~g}, 10 \mathrm{mmol})$ in tetrahydrofuran $(20 \mathrm{~mL})$, was added by means of a syringe. After stirring over night at room temperature the solvent was removed in vacuo and the mixture quenched with methanol $(100 \mathrm{~mL})$. The resulting yellow solid was separated from the solution in the centrifuge and dried in vacuo to yield $0.79 \mathrm{~g}(20 \%)$. ${ }^{1} \mathrm{H}$ NMR $\left(200 \mathrm{MHz}, \mathrm{C}_{6} \mathrm{D}_{6}\right.$ ): $\delta=0.81-1.10$ (mult, $12 \mathrm{H}, \mathrm{CH}_{2}$ Cy), 1.48 (mult, 8H, CH $\mathrm{CH}_{2} \mathrm{Cy}$ ), 2.07 (s, 3H, p- $\mathrm{CH}_{3} \mathrm{Mes}$ ), 2.20 (mult, 2H, P-CH Cy), 2.90 (s, 6H, o- $\mathrm{CH}_{3} \mathrm{Mes}$ ), 6.08 (s, 2H, CH Mes), 7.00 (mult, 12H, CH Ph), 7.74 (mult, $8 \mathrm{H}$, CH Ph) ppm. ${ }^{31} \mathrm{P}\left\{{ }^{1} \mathrm{H}\right\}$ NMR $\left(81 \mathrm{MHz}, \mathrm{C}_{6} \mathrm{D}_{6}\right): \delta=21.1 \mathrm{ppm}$. IR ( $\mathrm{KBr}$ disk): $\widetilde{v}=3050(\nu \mathrm{C}-\mathrm{H}$ aromatic, $\mathrm{w}), 2927,2851$, $2799(\nu \mathrm{C}-\mathrm{H}$ aliphatic, $\mathrm{m}), 1482(\nu \mathrm{C}-\mathrm{C}$ aromatic, $\mathrm{w}), 1435$, 1384 ( $\delta \mathrm{C}-\mathrm{H}$ aliphatic, w), 1090 ( $v \mathrm{P}-\mathrm{C}$, vs), 741, 723 ( $\delta \mathrm{C}-\mathrm{H}$ aromatic, $\mathrm{w}) \mathrm{cm}^{-1}$. This compound was used without further purification.

[Ni(L)MesPnBuPh$]$ (K3). 4,4,5,5,6,6,6-Heptafluoro-3oxo-2-[pyrrolidin-(2Z)-ylidene]hexanenitrile (HL, $0.61 \mathrm{~g}$, $2.0 \mathrm{mmol}$ ) was dissolved in toluene $(15 \mathrm{~mL})$, sodium bis(trimethylsilyl)amide $(0.6 \mathrm{M}$ in toluene, $3.3 \mathrm{~mL}, 2.0 \mathrm{mmol})$ was added, and the mixture was stirred. The deprotonated ligand was added by means of a syringe to a solution of the $\left[\mathrm{NiBrMes}(\mathrm{P} n \mathrm{BuPh})_{2}\right]$ complex $3 \mathbf{b}(1.50 \mathrm{~g}, 2.00 \mathrm{mmol})$ in toluene $(200 \mathrm{~mL})$ and the reaction mixture stirred overnight. After filtration of the solution over Celite, the solvent was removed in vacuo and the complex purified via column chromatography on neutral alumina. Elution with n-hexane yielded triphenylphosphane, and the complex was subsequently eluted with diethylether yielding $0.58 \mathrm{~g}$ of a yellow solid (40\%). ${ }^{1} \mathrm{H}$ NMR $\left(200 \mathrm{MHz}, \mathrm{C}_{6} \mathrm{D}_{6}\right): \delta=0.58(\mathrm{t}$, $3 \mathrm{H}, \mathrm{CH}_{3} \mathrm{Bu}$ ), 0.83 (mult, $2 \mathrm{H}, \mathrm{CH}_{2} \mathrm{CH}_{2} \mathrm{CH}_{2} \mathrm{~N}$ ), 0.93 (mult, $2 \mathrm{H}, \mathrm{CH}_{2} \mathrm{Bu}$ ), 1.05 (mult, 2H, $\mathrm{CH}_{2} \mathrm{Bu}$ ), 1.55 (q, 2H, $\mathrm{CH}_{2}$ $\mathrm{Bu}), 2.18$ (s, 3H, p-CH $\mathrm{CH}_{3} \mathrm{Mes}$ ), 2.36 (t, $2 \mathrm{H}, \mathrm{CH}_{2} \mathrm{CH}_{2} \mathrm{CH}_{2} \mathrm{~N}$ ), 2.60 (t, 2H, $\mathrm{CH}_{2} \mathrm{CH}_{2} \mathrm{CH}_{2} \mathrm{~N}$ ), 2.89 (s, 6H, o- $\mathrm{CH}_{3} \mathrm{Mes}$ ), 6.47 (s, 2H, CH Mes), 7.05 (mult, 6H, CH $\mathrm{PPh}_{2}$ ), 7.51 (mult, 4H, CH PPh 2 ) ppm. ${ }^{13} \mathrm{C}\left\{{ }^{1} \mathrm{H}\right\}$ NMR $\left(126 \mathrm{MHz}, \mathrm{C}_{6} \mathrm{D}_{6}\right): \delta$ $=13.4\left(\mathrm{PCH}_{2} \mathrm{CH}_{2} \mathrm{CH}_{2} \mathrm{CH}_{3}\right), 20.3\left(\mathrm{CH}_{2} \mathrm{CH}_{2} \mathrm{CH}_{2} \mathrm{~N}\right), 20.6$ (p- $\mathrm{CH}_{3} \mathrm{Mes}$ ), 24.4 (d, ${ }^{3} \mathrm{~J}_{\mathrm{CP}}=13 \mathrm{~Hz}, \mathrm{PCH}_{2} \mathrm{CH}_{2} \mathrm{CH}_{2} \mathrm{CH}_{3}$ ), $25.0\left(\mathrm{~d},{ }^{1} \mathrm{~J}_{\mathrm{CP}}=29 \mathrm{~Hz}, \mathrm{PCH}_{2} \mathrm{CH}_{2} \mathrm{CH}_{2} \mathrm{CH}_{3}\right), 25.8\left(\mathrm{o}-\mathrm{CH}_{3}\right.$ Mes), 26.1 (d, $\left.{ }^{2} \mathrm{~J}_{\mathrm{CP}}=3.8 \mathrm{~Hz}, \mathrm{PCH}_{2} \mathrm{CH}_{2} \mathrm{CH}_{2} \mathrm{CH}_{3}\right), 38.8$ $\left(\mathrm{CH}_{2} \mathrm{CH}_{2} \mathrm{CH}_{2} \mathrm{~N}\right), 63.2\left(\mathrm{CH}_{2} \mathrm{CH}_{2} \mathrm{CH}_{2} \mathrm{~N}\right), 83.9(\mathrm{C}=\mathrm{C}-\mathrm{CN})$, $126.7\left(\mathrm{~d},{ }^{4} \mathrm{~J}_{\mathrm{CP}}=2.5 \mathrm{~Hz}, \mathrm{CH} \mathrm{Mes}\right), 130.1\left(\mathrm{~d},{ }^{3} \mathrm{~J}_{\mathrm{CP}}=2.5 \mathrm{~Hz}\right.$, m-CH $\mathrm{PPh}_{2}$ ), $131.0\left(\mathrm{~d},{ }^{1} \mathrm{~J}_{\mathrm{CP}}=39 \mathrm{~Hz}, \mathrm{i}-\mathrm{C} \mathrm{PPh}_{2}\right), 133.3$ $\left(\mathrm{d},{ }^{2} \mathrm{~J}_{\mathrm{CP}}=10 \mathrm{~Hz}\right.$, o-CH $\left.\mathrm{PPh}_{2}\right), 141.9\left(\mathrm{~d},{ }^{3} \mathrm{~J}_{\mathrm{CP}}=2.5 \mathrm{~Hz}\right.$, o-C Mes), 142.5 (d, $\left.{ }^{2} \mathrm{~J}_{C P}=48 \mathrm{~Hz}, \mathrm{i}-\mathrm{C} \mathrm{Mes}\right), 165.9$ (CO), $172.1(\mathrm{C}=\mathrm{C}-\mathrm{CN})$ ppm. ${ }^{31} \mathrm{P}\left\{{ }^{1} \mathrm{H}\right\} \quad \mathrm{NMR}\left(81 \mathrm{MHz}, \mathrm{C}_{6} \mathrm{D}_{6}\right)$ : 
$\delta=18.9$ ppm. ${ }^{19} \mathrm{~F}$ NMR $\left(471 \mathrm{MHz}, \mathrm{C}_{6} \mathrm{D}_{6}\right): \delta=-80.91$ $\left(\mathrm{t}, \mathrm{CF}_{2} \mathrm{CF}_{2} \mathrm{CF}_{3}\right),-114.93\left(\mathrm{q}, \mathrm{CF}_{2} \mathrm{CF}_{2} \mathrm{CF}_{3}\right),-125.36(\mathrm{t}$, $\left.\mathrm{CF}_{2} \mathrm{CF}_{2} \mathrm{CF}_{3}\right)$ ppm. IR (KBr disk): $\widetilde{v}=3060$ ( $v \mathrm{C}-\mathrm{H}$ aromatic, $\mathrm{w}), 2960,2872(\nu \mathrm{C}-\mathrm{H}$ aliphatic, $\mathrm{m}), 2218(\nu \mathrm{C} \equiv \mathrm{N}, \mathrm{s})$, $1591(\nu \mathrm{C}=\mathrm{O}$, vs), $1517(\nu \mathrm{C}-\mathrm{C}$ aromatic, s), $1434(\delta \mathrm{C}-\mathrm{H}$ aliphatic, s), 1270, 1229, 1197 ( $v \mathrm{C}-\mathrm{F}, \mathrm{vs}), 1112(v \mathrm{P}-\mathrm{C}, \mathrm{m})$, $749(\delta \mathrm{C}-\mathrm{H}$ aromatic, $\mathrm{m}) \mathrm{cm}^{-1}$. MS (ESI, $\left.\mathrm{CH}_{3} \mathrm{OH}\right): \mathrm{m} / z$ $(\%)=361\left(\left[\mathrm{Mes}-\mathrm{P}(n \mathrm{Bu}) \mathrm{Ph}_{2}\right]^{+}, 100 \%\right), 303$ (N,O-ligand: $\left.\left[\mathrm{C}_{10} \mathrm{H}_{6} \mathrm{~N}_{2} \mathrm{OF}_{7}\right]^{+}, 38\right), 263\left(\left[\mathrm{HPPh}_{3}\right]^{+}, 4\right), 249(9), 193(8), 114$ (8), 85 (21). MS (MALDI): $m / z(\%)=619\left(\left[\mathrm{M}-\mathrm{C}_{7} \mathrm{H}_{5} \mathrm{~N}\right]^{+}\right)$, $563\left(\left[\mathrm{M}-\mathrm{C}_{11} \mathrm{H}_{13} \mathrm{~N}\right]^{+}\right), 361$ ([Mes- $\left.\left.\mathrm{P}(n \mathrm{Bu}) \mathrm{Ph}_{2}\right]^{+}, 100 \%\right)$. $\mathrm{C}_{35} \mathrm{H}_{36} \mathrm{~F}_{7} \mathrm{~N}_{2} \mathrm{OPNi}$ (723.37): calcd. C 58.11, H 5.03, N 3.87; found C 57.9, H 5.3, N 3.7.

$\left[\mathrm{Ni}(\mathbf{L}) \mathrm{MesPnBu}_{2} \mathrm{Ph}\right](\mathbf{K} 4)$. The synthesis was carried out as for $\mathbf{K 3}$, except that the $\left[\mathrm{NiBrMes}\left(\mathrm{P} n \mathrm{Bu}_{2} \mathrm{Ph}\right)_{2}\right]$ complex $4 \mathbf{b}(1.41 \mathrm{~g}, 2.00 \mathrm{mmol})$ was used. Yield: $0.1 \mathrm{~g}(9 \%) .{ }^{1} \mathrm{H}$ NMR $\left(200 \mathrm{MHz}, \mathrm{C}_{6} \mathrm{D}_{6}\right): \delta=0.76\left(\mathrm{t}, 6 \mathrm{H}, \mathrm{CH}_{3} \mathrm{Bu}\right.$ ), 0.89 (mult, $2 \mathrm{H}, \mathrm{CH}_{2} \mathrm{CH}_{2} \mathrm{CH}_{2} \mathrm{~N}$ ), 1.19-1.47 (mult, $12 \mathrm{H}, \mathrm{CH}_{2} \mathrm{Bu}$ ), 2.23 (s, $3 \mathrm{H}, \mathrm{p}-\mathrm{CH}_{3} \mathrm{Mes}$ ), 2.33 (t, $2 \mathrm{H}, \mathrm{CH}_{2} \mathrm{CH}_{2} \mathrm{CH}_{2} \mathrm{~N}$ ), 2.58 (t, $2 \mathrm{H}, \mathrm{CH}_{2} \mathrm{CH}_{2} \mathrm{CH}_{2} \mathrm{~N}$ ), 2.87 (s, 6H, o- $\left.\mathrm{CH}_{3} \mathrm{Mes}\right), 6.57$ (s, 2H, CH Mes), 7.08 (mult, $3 \mathrm{H}, \mathrm{CH} \mathrm{Ph}$ ), 7.37 (mult, $2 \mathrm{H}, \mathrm{CH} \mathrm{Ph}$ ) ppm. $\left.{ }^{13} \mathrm{C}^{1}{ }^{1} \mathrm{H}\right\}$ NMR $\left(126 \mathrm{MHz}, \mathrm{C}_{6} \mathrm{D}_{6}\right): \delta=$ $14.0\left(\mathrm{PCH}_{2} \mathrm{CH}_{2} \mathrm{CH}_{2} \mathrm{CH}_{3}\right), 20.6\left(\mathrm{CH}_{2} \mathrm{CH}_{2} \mathrm{CH}_{2} \mathrm{~N}\right), 21.0$ (p$\mathrm{CH}_{3} \mathrm{Mes}$ ), 21.7 (d, ${ }^{1} \mathrm{~J}_{\mathrm{CP}}=25 \mathrm{~Hz}, \mathrm{PCH}_{2} \mathrm{CH}_{2} \mathrm{CH}_{2} \mathrm{CH}_{3}$ ), $25.0\left(\mathrm{~d},{ }^{3} \mathrm{~J}_{\mathrm{CP}}=14 \mathrm{~Hz}, \mathrm{PCH}_{2} \mathrm{CH}_{2} \mathrm{CH}_{2} \mathrm{CH}_{3}\right), 26.1\left(\mathrm{o}-\mathrm{CH}_{3}\right.$ Mes), $26.2\left(\mathrm{PCH}_{2} \mathrm{CH}_{2} \mathrm{CH}_{2} \mathrm{CH}_{3}\right), 39.1\left(\mathrm{CH}_{2} \mathrm{CH}_{2} \mathrm{CH}_{2} \mathrm{~N}\right), 63.4$ $\left(\mathrm{CH}_{2} \mathrm{CH}_{2} \mathrm{CH}_{2} \mathrm{~N}\right), 84.5(\mathrm{C}=\mathrm{C}-\mathrm{CN}), 126.9\left(\mathrm{~d},{ }^{4} \mathrm{~J}_{\mathrm{CP}}=2.5 \mathrm{~Hz}\right.$, CH Mes), 130.1 (m-CH PPh), 131.7 (d, ${ }^{2} \mathrm{~J}_{\mathrm{CP}}=8 \mathrm{~Hz}, \mathrm{o}-\mathrm{CH}$ $\mathrm{PPh}), 132.5$ (d, ${ }^{1} \mathrm{~J}_{C P}=38 \mathrm{~Hz}$, i-C PPh), 133.6 (p-CH PPh), $142.5\left(\mathrm{~d},{ }^{3} \mathrm{~J}_{C P}=1.3 \mathrm{~Hz}, \mathrm{o}-\mathrm{C} \mathrm{Mes}\right), 142.9\left(\mathrm{~d},{ }^{2} \mathrm{~J}_{\mathrm{CP}}=47 \mathrm{~Hz}\right.$, iC Mes), $166.0\left(\mathrm{t},{ }^{2} \mathrm{~J}_{F C}=23 \mathrm{~Hz}, \mathrm{CO}\right), 172.1(\mathrm{C}=\mathrm{C}-\mathrm{CN}) \mathrm{ppm}$. ${ }^{31} \mathrm{P}\left\{{ }^{1} \mathrm{H}\right\}$ NMR $\left(81 \mathrm{MHz}, \mathrm{C}_{6} \mathrm{D}_{6}\right): \delta=11.9 \mathrm{ppm} .{ }^{19} \mathrm{~F}$ NMR $\left(471 \mathrm{MHz}, \mathrm{C}_{6} \mathrm{D}_{6}\right): \delta=-80.80\left(\mathrm{t}, \mathrm{CF}_{2} \mathrm{CF}_{2} \mathrm{CF}_{3}\right),-115.15(\mathrm{q}$, $\left.\mathrm{CF}_{2} \mathrm{CF}_{2} \mathrm{CF}_{3}\right),-125.68$ (t, $\left.\mathrm{CF}_{2} \mathrm{CF}_{2} \mathrm{CF}_{3}\right) \mathrm{ppm}$. IR ( $\mathrm{KBr}$ disk): $\widetilde{v}=2959,2931,2872(v \mathrm{C}-\mathrm{H}$ aliphatic, $\mathrm{s}), 2214(\nu \mathrm{C} \equiv \mathrm{N}$, s), $1587(v \mathrm{C}=\mathrm{O}, \mathrm{vs}), 1514$ ( $v \mathrm{C}-\mathrm{C}$ aromatic, s), 1450, 1435, 1379 ( $\delta \mathrm{C}-\mathrm{H}$ aliphatic, s), 1260, 1230, 1185 ( $\nu \mathrm{C}-\mathrm{F}, \mathrm{vs}), 1113$ $(\nu \mathrm{P}-\mathrm{C}, \mathrm{s}), 749(\delta \mathrm{C}-\mathrm{H}$ aromatic, $\mathrm{m}) \mathrm{cm}^{-1}$. MS (EI): $\mathrm{m} / z$ $(\%)=703\left([\mathrm{M}]^{\bullet+}, 0.3 \%\right), 702\left([\mathrm{M}-\mathrm{H}]^{+}, 0.5\right), 363([\mathrm{M}-$ Mes- $\left.\left.\mathrm{P}(n \mathrm{Bu})_{2} \mathrm{Ph}\right]^{+}, 1\right), 342\left(\left[\mathrm{M}-\mathrm{C}_{14} \mathrm{H}_{15} \mathrm{~N}_{2} \mathrm{OF}_{7}\right]^{+}, 46\right), 341$ ([Mes- $\left.\left.\mathrm{P}(n \mathrm{Bu})_{2} \mathrm{Ph}\right]^{+}, 100\right), 241(7), 222\left(\left[\mathrm{P}(n \mathrm{Bu})_{2} \mathrm{Ph}\right]^{+}, 3\right)$, 192 (7), 138 (17), 109 (16).

$\left[\mathrm{Ni}(\mathbf{L}) \mathrm{MesPnBu}_{3}\right](\mathbf{K} 5)$. The $\left[\mathrm{Ni}(\mathbf{L}) \mathrm{MesPPh}_{3}\right]$ complex K2 $(0.78 \mathrm{~g}, 1.0 \mathrm{mmol})$ was dissolved in toluene p.a. $(40 \mathrm{~mL})$, and tri-n-butylphosphane $(0.40 \mathrm{~g}, 2.0 \mathrm{mmol})$ was added. The mixture was stirred for 6 days at room temperature and the substitution of the phosphane monitored with ${ }^{31} \mathrm{P}\left\{{ }^{1} \mathrm{H}\right\}$ NMR spectroscopy. After complete substitution, the solvent was removed in vacuo and the complex purified via column chromatography on neutral alumina. Elution with n-hexane first yielded triphenylphosphane and then the complex which was recrystallized from $\mathrm{n}$-pentane yielding $0.24 \mathrm{~g}$ red-brown crystals (35\%). ${ }^{1} \mathrm{H}$ NMR $\left(500 \mathrm{MHz}, \mathrm{C}_{6} \mathrm{D}_{6}\right): \delta=$ $0.82\left(\mathrm{t}, 11 \mathrm{H}, \mathrm{CH}_{3} \mathrm{Bu}\right.$ and $\mathrm{CH}_{2} \mathrm{CH}_{2} \mathrm{CH}_{2} \mathrm{~N}$ ), 1.19 (mult, $14 \mathrm{H}$, $\mathrm{CH}_{2} \mathrm{Bu}$ ), 1.31 (mult, 7H, $\mathrm{CH}_{2} \mathrm{Bu}$ ), 2.23 (s, 3H, p- $\mathrm{CH}_{3} \mathrm{Mes}$ ), 2.32 (t, $2 \mathrm{H}, \mathrm{CH}_{2} \mathrm{CH}_{2} \mathrm{CH}_{2} \mathrm{~N}$ ), 2.57 (t, $2 \mathrm{H}, \mathrm{CH}_{2} \mathrm{CH}_{2} \mathrm{CH}_{2} \mathrm{~N}$ ),
3.03 (s, 6H, o-CH $\mathrm{Mes}$ ), 6.60 (s, 2H, CH Mes) ppm. ${ }^{13} \mathrm{C}\left\{{ }^{1} \mathrm{H}\right\}$ NMR $\left(126 \mathrm{MHz}, \mathrm{C}_{6} \mathrm{D}_{6}\right): \delta=14.1\left(\mathrm{PCH}_{2} \mathrm{CH}_{2} \mathrm{CH}_{2} \mathrm{CH}_{3}\right)$, $20.6 \quad\left(\mathrm{p}-\mathrm{CH}_{3} \quad \mathrm{Mes}\right), \quad 21.0 \quad\left(\mathrm{CH}_{2} \mathrm{CH}_{2} \mathrm{CH}_{2} \mathrm{~N}\right), 23.4 \quad$ (d, $\left.{ }^{1} \mathrm{~J}_{\mathrm{CP}}=24 \mathrm{~Hz}, \quad \mathrm{PCH}_{2} \mathrm{CH}_{2} \mathrm{CH}_{2} \mathrm{CH}_{3}\right), \quad 25.3 \quad\left(\mathrm{~d},{ }^{3} \mathrm{~J}_{\mathrm{CP}}=\right.$ $\left.13 \mathrm{~Hz}, \quad \mathrm{PCH}_{2} \mathrm{CH}_{2} \mathrm{CH}_{2} \mathrm{CH}_{3}\right), \quad 26.2\left(\mathrm{o}-\mathrm{CH}_{3} \mathrm{Mes}\right), \quad 26.6$ $\left(\mathrm{PCH}_{2} \mathrm{CH}_{2} \mathrm{CH}_{2} \mathrm{CH}_{3}\right), \quad 39.2 \quad\left(\mathrm{CH}_{2} \mathrm{CH}_{2} \mathrm{CH}_{2} \mathrm{~N}\right), \quad 63.3$ $\left(\mathrm{CH}_{2} \mathrm{CH}_{2} \mathrm{CH}_{2} \mathrm{~N}\right), \quad 84.3 \quad(\mathrm{C}=\mathrm{C}-\mathrm{CN}), \quad 117.3(\mathrm{CN}), \quad 126.8$ (CH Mes), $133.5\left(\mathrm{~d},{ }^{5} \mathrm{~J}_{\mathrm{CP}}=2.5 \mathrm{~Hz}, \mathrm{p}-\mathrm{C}\right.$ Mes), $142.1(\mathrm{~d}$, ${ }^{3} \mathrm{~J}_{C P}=2.5 \mathrm{~Hz}$, o-C Mes $), 143.5\left(\mathrm{~d},{ }^{2} \mathrm{~J}_{C P}=48 \mathrm{~Hz}, \mathrm{i}-\mathrm{C} \mathrm{Mes}\right)$, $166.0(\mathrm{CO}), 172.1(\mathrm{C}=\mathrm{C}-\mathrm{CN}) \mathrm{ppm} .{ }^{31} \mathrm{P}\left\{{ }^{1} \mathrm{H}\right\} \mathrm{NMR}(81 \mathrm{MHz}$, $\left.\mathrm{C}_{6} \mathrm{D}_{6}\right): \delta=10.4 \mathrm{ppm} .{ }^{19} \mathrm{~F}$ NMR $\left(471 \mathrm{MHz}, \mathrm{C}_{6} \mathrm{D}_{6}\right): \delta=-80.87$ (t, $\mathrm{CF}_{2} \mathrm{CF}_{2} \mathrm{CF}_{3}$ ), -115.14 (mult, $\mathrm{CF}_{2} \mathrm{CF}_{2} \mathrm{CF}_{3}$ ), -125.59 (t, $\left.\mathrm{CF}_{2} \mathrm{CF}_{2} \mathrm{CF}_{3}\right) \mathrm{ppm}$. IR (KBr disk): $\widetilde{v}=3174(\nu \mathrm{C}-\mathrm{H}$ aromatic, w), 2961, 2930, 2873 ( $\nu \mathrm{C}-\mathrm{H}$ aliphatic, s), $2211(\nu \mathrm{C} \equiv \mathrm{N}, \mathrm{m})$, $1589(\nu \mathrm{C}=\mathrm{O}, \mathrm{s}), 1522(\nu \mathrm{C}-\mathrm{C}$ aromatic, $s), 1464,1435,1378$ $(\delta \mathrm{C}-\mathrm{H}$ aliphatic, $\mathrm{m}), 1261,1233,1195(\nu \mathrm{C}-\mathrm{F}, \mathrm{vs}) \mathrm{cm}^{-1}$. MS (EI): $m / z(\%)=683\left([\mathrm{M}]^{\bullet+}, 0.3 \%\right), 323(33), 322([\mathrm{M}-$ $\left.\left.\mathrm{C}_{14} \mathrm{H}_{15} \mathrm{~N}_{2} \mathrm{OF}_{7}\right]^{+}, 15\right), 321$ ([Mes- $\left.\left.\mathrm{P}(n \mathrm{Bu})_{3}\right]^{+}, 100\right), 192(8)$,

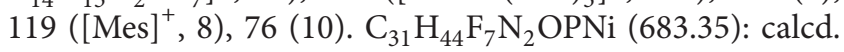
C 54.48, H 6.50, N 4.10; found C 54.5, H 6.7, N 4.0.

$\left[\mathrm{Ni}(\mathbf{L}) \mathrm{MesP}(\mathrm{OEt})_{3}\right](\mathbf{K} \mathbf{6})$. The $\left[\mathrm{NiBrMes}\left(\mathrm{P}(\mathrm{OEt})_{3}\right)_{2}\right]$ complex $\mathbf{6 b}(0.53 \mathrm{~g}, 0.90 \mathrm{mmol})$ was dissolved in toluene $(30 \mathrm{~mL}) . \quad 4,4,5,5,6,6,6$-Heptafluoro-3-oxo-2-[pyrrolidin(2Z)ylidene]hexanenitrile $\mathrm{HL}(0.27 \mathrm{~g}, 0.90 \mathrm{mmol})$ and sodium bis(trimethylsilyl)amide $(0.6 \mathrm{M}$ in toluene, $1.62 \mathrm{~mL}$, $1.0 \mathrm{mmol}$ ) were added. The mixture was stirred for $2 \mathrm{~h}$. After filtration over Celite and removal of the solvent in vacuo, the solid was recrystallized from methanol. Crystals suitable for $\mathrm{X}$-ray analysis were obtained at $-6^{\circ} \mathrm{C}$. Yield: $0.21 \mathrm{~g}$ of orange crystals $(36 \%) .{ }^{1} \mathrm{H}$ NMR $\left(200 \mathrm{MHz}, \mathrm{C}_{6} \mathrm{D}_{6}\right)$ : $\delta=0.79\left(\mathrm{p}, 2 \mathrm{H}, \mathrm{CH}_{2} \mathrm{CH}_{2} \mathrm{CH}_{2} \mathrm{~N}\right), 0.94\left(\mathrm{t}, 9 \mathrm{H}, \mathrm{OCH}_{2} \mathrm{CH}_{3}\right)$, 2.22 (s, 3H, p- $\mathrm{CH}_{3} \mathrm{Mes}$ ), 2.34 (t, $2 \mathrm{H}, \mathrm{CH}_{2} \mathrm{CH}_{2} \mathrm{CH}_{2} \mathrm{~N}$ ), 2.55 (t, $2 \mathrm{H}, \mathrm{CH}_{2} \mathrm{CH}_{2} \mathrm{CH}_{2} \mathrm{~N}$ ), 3.03 (s, $6 \mathrm{H}, \mathrm{o}-\mathrm{CH}_{3} \mathrm{Mes}$ ), 3.71 (q, $6 \mathrm{H}, \mathrm{OCH}_{2} \mathrm{CH}_{3}$ ), 6.63 (s, 2H, CH Mes) ppm. ${ }^{13} \mathrm{C}\left\{{ }^{1} \mathrm{H}\right\} \mathrm{NMR}$ $\left(126 \mathrm{MHz}, \mathrm{C}_{6} \mathrm{D}_{6}\right): \delta=16.0\left(\mathrm{~d},{ }^{3} \mathrm{~J}_{\mathrm{CP}}=6,3 \mathrm{~Hz}, \mathrm{OCH}_{2} \mathrm{CH}_{3}\right)$, $20.1\left(\mathrm{CH}_{2} \mathrm{CH}_{2} \mathrm{CH}_{2} \mathrm{~N}\right), 20.7$ (p- $\mathrm{CH}_{3}$ Mes), $25.6\left(\mathrm{o}-\mathrm{CH}_{3}\right.$ Mes), $38.9\left(\mathrm{~d}, \mathrm{~J}=6.3 \mathrm{~Hz}, \mathrm{CH}_{2} \mathrm{CH}_{2} \mathrm{CH}_{2} \mathrm{~N}\right), 61.3\left(\mathrm{~d},{ }^{2} \mathrm{~J}_{\mathrm{CP}}=\right.$ $\left.5.0 \mathrm{~Hz}, \mathrm{OCH}_{2} \mathrm{CH}_{3}\right), 62.5\left(\mathrm{CH}_{2} \mathrm{CH}_{2} \mathrm{CH}_{2} \mathrm{~N}\right), 83.6(\mathrm{C}=\mathrm{C}-\mathrm{CN})$, $126.4\left(\mathrm{~d},{ }^{4} \mathrm{~J}_{C P}=3.8 \mathrm{~Hz}, \mathrm{CH}\right.$ Mes $), 133.4\left(\mathrm{~d},{ }^{5} \mathrm{~J}_{\mathrm{CP}}=1.3 \mathrm{~Hz}\right.$, p-C Mes), $141.2\left(\mathrm{~d},{ }^{2} \mathrm{~J}_{\mathrm{CP}}=65.5 \mathrm{~Hz}, \mathrm{i}-\mathrm{C} \mathrm{Mes}\right), 142.7$ (d, ${ }^{3} \mathrm{~J}_{C P}=2.5 \mathrm{~Hz}$, o-C Mes), $166.4\left(\mathrm{t},{ }^{2} \mathrm{~J}_{F C}=23.9 \mathrm{~Hz}, \mathrm{CO}\right)$, $172.6(\mathrm{C}=\mathrm{C}-\mathrm{CN}) \mathrm{ppm} .{ }^{31} \mathrm{P}\left\{{ }^{1} \mathrm{H}\right\} \quad \mathrm{NMR}\left(81 \mathrm{MHz}, \mathrm{C}_{6} \mathrm{D}_{6}\right)$ : $\delta=105.0 \mathrm{ppm} .{ }^{19} \mathrm{~F}$ NMR $\left(471 \mathrm{MHz}, \mathrm{C}_{6} \mathrm{D}_{6}\right): \delta=-80.93$ (t, $\mathrm{CF}_{2} \mathrm{CF}_{2} \mathrm{CF}_{3}$ ), -115.07 (mult, $\mathrm{CF}_{2} \mathrm{CF}_{2} \mathrm{CF}_{3}$ ), -125.94 (t, $\mathrm{CF}_{2} \mathrm{CF}_{2} \mathrm{CF}_{3}$ ) ppm. IR (KBr disk): $\widetilde{v}=2986,2938,2908$ $(v \mathrm{C}-\mathrm{H}$ aliphatic, $\mathrm{m}), 2213(v \mathrm{C} \equiv \mathrm{N}, \mathrm{m}), 1592(\nu \mathrm{C}=\mathrm{O}, v s)$, $1517(\nu \mathrm{C}-\mathrm{C}$ aromatic, s), $1436(\delta \mathrm{C}-\mathrm{H}$ aliphatic, $\mathrm{m}), 1275$, 1229, $1194(v \mathrm{C}-\mathrm{F}, \mathrm{vs}), 1024,777,740(\nu \mathrm{P}-\mathrm{O}-\mathrm{C}, \mathrm{vs}) \mathrm{cm}^{-1}$. MS (ESI): $m / z(\%)=670\left([\mathrm{M}+\mathrm{Na}]^{+}, 85 \%\right), 647\left([\mathrm{M}]^{\bullet+}, 28\right)$, 545 (50), 480 ([M-P $\left.\left.(\mathrm{OEt})_{3}\right]^{+}, 8\right), 285$ ([Mes-P(OEt) $\left.]_{3}\right]^{+}, 100$ ), 201 (45). $\mathrm{C}_{25} \mathrm{H}_{32} \mathrm{~F}_{7} \mathrm{~N}_{2} \mathrm{O}_{4} \mathrm{PNi}$ (647.26): calcd. C 46.39, $\mathrm{H} 4.99$, N 4.33; found C 46.1, H 5.0, N 4.3.

$\left[\mathrm{Ni}(\mathbf{L}) \mathrm{MesPC} y \mathrm{Ph}_{2}\right](\mathbf{K} 7)$. The $\left[\mathrm{NiBrMes}\left(\mathrm{PCyPh}_{2}\right)_{2}\right]$ complex $7 \mathbf{b}(0.79 \mathrm{~g}, 1.0 \mathrm{mmol})$ and 4,4,5,5,6,6,6-heptafluoro3-oxo-2-[pyrrolidin-(2Z)-ylidene]hexanenitrile HL $(0.30 \mathrm{~g}$, $1.0 \mathrm{mmol}$ ) were dissolved in toluene $(60 \mathrm{~mL})$. Sodium 
bis(trimethylsilyl)amide (0.6 M in toluene, $1.8 \mathrm{~mL}, 1.1 \mathrm{mmol}$ ) was added and the mixture was stirred for 3 days. After filtration over Celite and removal of the solvent in vacuo, the solid was stirred in methanol $(50 \mathrm{~mL})$. After removing remaining solid with the centrifuge, the solvent was removed in vacuo and the solid dried in vacuo. The solid was stirred in hexane $(40 \mathrm{~mL})$ for one day. After filtration of undissolved solid, the solvent was removed in vacuo and the resulting oil recrystallized from methanol. Crystals suitable for X-ray analysis were obtained at $-30^{\circ} \mathrm{C}$. Yield: $0.20 \mathrm{~g}$ dark brown needle-like crystals (27\%). ${ }^{1} \mathrm{H}$ NMR $\left(200 \mathrm{MHz}, \mathrm{C}_{6} \mathrm{D}_{6}\right): \delta=$ 0.83 (mult, 2H, $\mathrm{CH}_{2} \mathrm{CH}_{2} \mathrm{CH}_{2} \mathrm{~N}$ ), 0.92-1.04 (mult, 5H, $\mathrm{CH}_{2}$ Cy), 1.48-1.55 (mult, 5H, CH $\mathrm{CH}_{2} \mathrm{Cy}$ ), 2.11 (s, 3H, p-CH $\mathrm{CH}_{3} \mathrm{Mes}$ ), 2.14 (m, 1H, P-C1H Cy), 2.37 (t, 2H, $\mathrm{CH}_{2} \mathrm{CH}_{2} \mathrm{CH}_{2} \mathrm{~N}$ ), 2.57 $\left(\mathrm{t}, 2 \mathrm{H}, \mathrm{CH}_{2} \mathrm{CH}_{2} \mathrm{CH}_{2} \mathrm{~N}\right.$ ), 2.90 (s, 6H, o- $\mathrm{CH}_{3} \mathrm{Mes}$ ), 6.27 (s, 2H, CH Mes), 7.00 (mult, 6H, CH PPh ${ }_{2}$ ), 7.53 (mult, 4H, o$\mathrm{CH} \mathrm{PPh}$ ) ppm. ${ }^{13} \mathrm{C}\left\{{ }^{1} \mathrm{H}\right\}$ NMR $\left(126 \mathrm{MHz}, \mathrm{C}_{6} \mathrm{D}_{6}\right): \delta=20.6$ $\left(\mathrm{CH}_{2} \mathrm{CH}_{2} \mathrm{CH}_{2} \mathrm{~N}\right.$ ), 20.7 (p- $\mathrm{CH}_{3} \mathrm{Mes}$ ), 26.4 (o- $\mathrm{CH}_{3} \mathrm{Mes}$ ), 26.7 $\left(\mathrm{C}_{4} \mathrm{H}_{2} \mathrm{Cy}\right), 27.9$ (d, $\left.{ }^{2} \mathrm{~J}_{\mathrm{CP}}=11 \mathrm{~Hz}, \mathbf{C} 2 \mathrm{H}_{2} \mathrm{Cy}\right), 29.3\left(\mathbf{C} 3 \mathrm{H}_{2} \mathrm{Cy}\right)$, $37.3\left(\mathrm{~d},{ }^{1} \mathrm{~J}_{\mathrm{CP}}=19 \mathrm{~Hz}, \mathrm{P}-\mathrm{C} 1 \mathrm{H} \mathrm{Cy}\right), 39.3\left(\mathrm{CH}_{2} \mathrm{CH}_{2} \mathrm{CH}_{2} \mathrm{~N}\right)$, $63.7\left(\mathrm{CH}_{2} \mathrm{CH}_{2} \mathrm{CH}_{2} \mathrm{~N}\right), 84.5(\mathrm{C}=\mathrm{C}-\mathrm{CN}), 117.3(\mathrm{CN}), 127.0$ $\left(\mathrm{d},{ }^{4} \mathrm{~J}_{\mathrm{CP}}=2.5 \mathrm{~Hz}, \mathrm{CH} \mathrm{Mes}\right), 130.2\left(\mathrm{~m}-\mathrm{CH} \mathrm{PPh}_{2}\right), 130.7(\mathrm{~d}$, $\left.{ }^{1} \mathrm{~J}_{\mathrm{CP}}=40 \mathrm{~Hz}, \mathrm{i}-\mathrm{C} \mathrm{PPh}_{2}\right), 133.4\left(\mathrm{p}-\mathrm{CH} \mathrm{PPh}_{2}\right), 134.7\left(\mathrm{~d},{ }^{2} \mathrm{~J}_{\mathrm{CP}}=\right.$ $9 \mathrm{~Hz}, \mathrm{o}-\mathrm{CH} \mathrm{PPh}$ ) $, 141.8\left(\mathrm{~d},{ }^{3} \mathrm{~J}_{\mathrm{CP}}=2.5 \mathrm{~Hz}, \mathrm{o}-\mathrm{C} \mathrm{Mes}\right), 142.9$ (d, ${ }^{2} \mathrm{~J}_{\mathrm{CP}}=44 \mathrm{~Hz}$, i-C Mes), 166.0 (CO), 172.5 (C=C-CN) ppm. ${ }^{31} \mathrm{P}\left\{{ }^{1} \mathrm{H}\right\}$ NMR $\left(81 \mathrm{MHz}, \mathrm{C}_{6} \mathrm{D}_{6}\right): \delta=27.9 \mathrm{ppm} .{ }^{19} \mathrm{~F} \mathrm{NMR}$ $\left(471 \mathrm{MHz}, \mathrm{C}_{6} \mathrm{D}_{6}\right): \delta=-80.82\left(\mathrm{t}, \mathrm{CF}_{2} \mathrm{CF}_{2} \mathrm{CF}_{3}\right),-114.53$ (mult, $\mathrm{CF}_{2} \mathrm{CF}_{2} \mathrm{CF}_{3}$ ), $-125.03\left(\mathrm{t}, \mathrm{CF}_{2} \mathrm{CF}_{2} \mathrm{CF}_{3}\right) \mathrm{ppm}$. IR ( $\mathrm{KBr}$ disk): $\widetilde{v}=3082,3057(\nu \mathrm{C}-\mathrm{H}$ aromatic, $\mathrm{W}), 2934,2854$ ( $\nu \mathrm{C}-\mathrm{H}$ aliphatic, s), $2211(\nu \mathrm{C} \equiv \mathrm{N}, \mathrm{m}), 1588(\nu \mathrm{C}=\mathrm{O}, \mathrm{vs})$, 1515,1484 ( $v \mathrm{C}-\mathrm{C}$ aromatic, vs), $1433(\delta \mathrm{C}-\mathrm{H}$ aliphatic, s), 1266, 1231, 1193 ( $\nu \mathrm{C}-\mathrm{F}$, vs), $1110(\nu \mathrm{P}-\mathrm{C}, \mathrm{m}), 750,736$ $(\delta \mathrm{C}-\mathrm{H}$ aromatic, $\mathrm{m}) \mathrm{cm}^{-1}$. MS $(\mathrm{EI}): \mathrm{m} / z(\%)=748\left([\mathrm{M}]^{\bullet+}\right.$, 2\%), $387\left(\left[\mathrm{Mes}-\mathrm{PCyPh}_{2}\right]^{+}, 100\right), 268\left(\left[\mathrm{PCyPh}_{2}\right]^{+}, 64\right), 186$ (47), 183 (29), 108 (49). MS (ESI, $\left.\mathrm{CH}_{3} \mathrm{OH} / \mathrm{H}_{2} \mathrm{O}\right): \mathrm{m} / z$ (\%) $=771\left([\mathrm{M}+\mathrm{Na}]^{+}, 3 \%\right), 629\left([\mathrm{M}-\mathrm{Mes}]^{+}, 6\right),\left(\left[\mathrm{Mes}-\mathrm{PCyPh}_{2}\right]^{+}\right.$, 44), $305\left(\left[\mathrm{C}_{10} \mathrm{H}_{8} \mathrm{~N}_{2} \mathrm{OF}_{7}\right]^{+}, 100\right) . \mathrm{C}_{37} \mathrm{H}_{38} \mathrm{~F}_{7} \mathrm{~N}_{2} \mathrm{OPNi}(748.20)$ : calcd. C 59.39, H 5.13, N 3.74; found C 59.4, H 5.1, N 3.5.

4.1. Crystal Structure Determinations. Crystals of complexes K5, K6, and K7 suitable for X-ray study were selected by means of a polarization microscope and investigated with a STOE Imaging Plate Diffraction System, using graphite monochromatized MoK $\alpha$ radiation $(\lambda=0.71073 \AA)$. Unit cell parameters were determined by least-squares refinements on the positions of 8000 reflections, in the $\theta$ range $2.1^{\circ}$ to $25.1^{\circ}, 2.25^{\circ}$ to $25.95^{\circ}$, and $2.0^{\circ}$ to $25.65^{\circ}$, respectively. Space group type no. 14 was uniquely determined for K5. For K6 and K7 triclinic symmetry was found consistent with space group types $P 1$ and $P \overline{1}$. In accordance with Estatistics for both compounds significantly better results were observed with structural models in the centrosymmetric space group type in the course of structure refinements, taking into account a 1:1 conformational disorder of the ethoxy groups of the phosphite ligand in the case of K6. Corrections for Lorentz and polarization effects were applied. The structures were solved by direct methods [48] and subsequent $\Delta F$-syntheses. Approximate positions of all but the hydrogen atoms of the disordered ethoxy groups of K6 and of the conformational disordered butyl groups of the tributylphosphane ligand of $\mathbf{K 5}$ were found in different stages of converging refinements by full-matrix least-squares calculations on $F^{2}$ [49]. Anisotropic displacement parameters were refined for all atoms heavier than hydrogen. With idealized bond lengths and angles assumed for all the $\mathrm{CH}$, $\mathrm{CH}_{2}$, and $\mathrm{CH}_{3}$ groups, the riding model was applied for the corresponding $\mathrm{H}$ atoms and their isotropic displacement parameters were constrained to $120 \%, 120 \%$, and $150 \%$ of the equivalent isotropic displacement parameters of the parent carbon atoms, respectively. In addition, the $\mathrm{H}$ atoms of the $\mathrm{CH}_{3}$ groups (with the exception of those within the phosphane butyl groups of $\mathbf{K 5}$ ) were allowed to rotate around the neighbouring $\mathrm{C}-\mathrm{C}$ bonds. Appropriate same distance and anisotropic displacement restraints had to be applied for the disordered carbon atoms of $\mathrm{K} 5$ and for the atoms of the $\mathrm{C}_{3} \mathrm{~F}_{7}$ groups of $\mathbf{K 5}$ and K6. CCDC-885214 (K5), CCDC-885215 (K6), and CCDC-885216 (K7) contain the supplementary crystallographic data (excluding structure factors) for this paper. These data can be obtained free of charge from The Cambridge Crystallographic Data Centre via http://www.ccdc.cam.ac.uk/data_request/cif.

4.2. Catalysis Experiments. General Procedure. $20 \mathrm{mg}$ of the catalyst complex were dissolved in toluene $(10 \mathrm{~mL})$ in a $100 \mathrm{~mL}$ steel autoclave with glass inlet under nitrogen atmosphere. Ethene (40 bar) and carbon monoxide (10 bar) were added and the reaction mixture was stirred for $20 \mathrm{~h}$ at $60^{\circ} \mathrm{C}$. The weight of the autoclave was measured before and after adding the gases to determine the mass of the gases. Potentially resulting solid was separated, washed with methanol, dried in vacuo, and characterized by IR spectroscopy. The remaining solution was analysed with GC/MS spectrometry.

Catalysis Experiment with $\left[N i(\mathbf{L}) M e s P(n B u) P h_{2}\right] \mathbf{K} 3$. Result: colourless, slightly cloudy solution. GC/MS: $10.8 \mathrm{~min}$ (n-butyldiphenylphosphane oxide, 64\%), $11.0 \mathrm{~min}$ (mesitylaldehyde, 10\%).

n-Butyldiphenylphosphane Oxide. Retention time: $10.8 \mathrm{~min}$; MS (EI): $m / z=258$ (fragment, relative intensity) ([M] $]^{\bullet+}, 5 \%$ ), $229\left(\left[\mathrm{C}_{2} \mathrm{H}_{5}\right]^{+}, 10\right), 216\left(\left[\mathrm{M}-\mathrm{C}_{3} \mathrm{H}_{6}\right]^{\bullet+}, 54\right), 215\left(\left[\mathrm{M}-\mathrm{C}_{3} \mathrm{H}_{7}\right]^{+}\right.$,

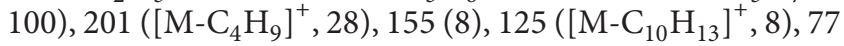
(Ph, 8).

Mesitylaldehyde. Retention time: $11.0 \mathrm{~min}$; MS (EI): $\mathrm{m} / z=$ 148 (fragment, relative intensity) $\left([\mathrm{M}]^{\bullet+}, 11 \%\right), 147\left([\mathrm{M}-\mathrm{H}]^{+}\right.$, 100), $119\left([\mathrm{M}-\mathrm{CHO}]^{+}, 10\right)$.

Catalysis Experiment with $\left[\mathrm{Ni}(\mathbf{L}) \mathrm{Mes} P(n \mathrm{Bu})_{3}\right] \mathbf{K} 5$. Result: colourless, slightly cloudy solution. GC/MS: $8.2 \mathrm{~min}$ (trin-butylphosphane oxide, 33\%), $11.0 \mathrm{~min}$ (mesitylaldehyde, $15 \%)$.

Tri-n-butylphosphane Oxide. Retention time: $8.2 \mathrm{~min}$; MS (EI): $m / z=218$ (fragment, relative intensity) $\left([\mathrm{M}]^{\bullet+}, 11 \%\right)$, 
$189\left(\left[\mathrm{M}-\mathrm{C}_{2} \mathrm{H}_{5}\right]^{+}, 74\right), 162\left(\left[\mathrm{M}-\mathrm{C}_{4} \mathrm{H}_{8}\right]^{\bullet+}, 52\right), 161([\mathrm{M}-$ $\left.\left.\mathrm{C}_{4} \mathrm{H}_{9}\right]^{+}, 35\right), 147\left(\left[\mathrm{M}-\mathrm{C}_{5} \mathrm{H}_{11}\right]^{+}, 59\right), 134$ (38), 120 (53), 92 $\left(\left[\mathrm{M}-\mathrm{C}_{9} \mathrm{H}_{18}\right]^{\bullet+}, 100\right), 78(48)$.

Catalysis Experiment with $\left[\mathrm{Ni}(\mathbf{L}) \mathrm{MesP}(\mathrm{OEt})_{3}\right]$ K6. Result: colourless, slightly cloudy solution. GC/MS: $4.3 \mathrm{~min}$ (triethylphosphate, 47\%), $11.0 \mathrm{~min}$ (mesitylaldehyde, 42\%).

Triethylphosphate. Retention time: $4.3 \mathrm{~min}$; MS (EI): $\mathrm{m} / z=$ 182 (fragment, relative intensity) $\left([\mathrm{M}]^{\bullet+}, 4 \%\right), 155$ ([M$\left.\left.\mathrm{C}_{2} \mathrm{H}_{3}\right]^{+}, 100\right), 127\left(\left[\mathrm{M}-\mathrm{C}_{4} \mathrm{H}_{7}\right]^{+}, 54\right), 109$ (27), 99 ([M$\left.\left.\mathrm{C}_{6} \mathrm{H}_{11}\right]^{+}, 65\right), 81(20)$.

Catalysis Experiment with $\left[\mathrm{Ni}(\mathbf{L}) \mathrm{MesPC} y \mathrm{Ph}_{2}\right]$ K7. Yield: $3.41 \mathrm{~g}$ polyketone. Efficiency: 2,200 g PK/g Ni.

\section{Conflict of Interests}

None of the authors of this work has a direct financial relation with the commercial identities mentioned in this publication.

\section{Acknowledgments}

M. M. Lindner thanks the Studienstiftung des deutschen Volkes for a Ph.D. scholarship. The authors thank Björn Hildebrandt for his valuable help in the preparation of various compounds.

\section{References}

[1] R. H. Crabtree, The Organometallic Chemistry of the Transition Metals, Wiley-Interscience, New York, NY, USA, 2nd edition, 1994.

[2] D. Steinborn, Grundlagen der metallorganischen Komplexkatalyse, Teubner, Wiesbaden, Germany, 1st edition, 2007.

[3] B. Cornils and W. A. Herrmann, Eds., Applied Homogeneous Catalysis with Organometallic Compounds vol. 1: Applications, VCH, Weinheim, Germany, 1996.

[4] P. Braunstein and N. M. Boag, "Alkyl, silyl, and phosphane ligands-classical ligands in nonclassical bonding modes," Angewandte Chemie-International Edition, vol. 40, pp. 2427-2433, 2001.

[5] L. A. Adrio and K. K. Hii, "Application of phosphine ligands in organic synthesis," Organometallic Chemistry, vol. 35, pp. 62-92, 2009.

[6] C. A. Streuli, "Determination of basicity of substituted phosphines by nonaqueous titrimetry," Analytical Chemistry, vol. 32, no. 8, pp. 985-987, 1960.

[7] W. M. A. Henderson Jr., "The basicity of phosphines," Journal of the American Chemical Society, vol. 82, no. 22, pp. 5791-5794, 1960.

[8] T. Allman and R. G. Goel, "The basicity of phosphines," Canadian Journal of Chemistry, vol. 60, no. 6, pp. 716-722, 1982.

[9] R. C. Bush and R. J. Angelici, "Phosphine basicities as determined by enthalpies of protonation," Inorganic Chemistry, vol. 27, no. 4, pp. 681-686, 1988.

[10] J. R. Sowa and R. J. Angelici, "Bidentate phosphine basicities as determined by enthalpies of protonation," Inorganic Chemistry, vol. 30, no. 18, pp. 3534-3537, 1991.

[11] A. Streitwieser, A. E. McKeown, F. Hasanayn, and N. R. Davis, "Basicity of some phosphines in THF," Organic Letters, vol. 7, no. 7, pp. 1259-1262, 2005.
[12] C. A. Tolman, "Steric effects of phosphorus ligands in organometallic chemistry and homogeneous catalysis," Chemical Reviews, vol. 77, no. 3, pp. 313-348, 1977.

[13] C. A. Tolman, "Electron donor-acceptor properties of phosphorus ligands. Substituent additivity," Journal of the American Chemical Society, vol. 92, no. 10, pp. 2953-2956, 1970.

[14] C. A. Tolman, "Phosphorus ligand exchange equilibria on zerovalent nickel. A dominant role for steric effects," Journal of the American Chemical Society, vol. 92, no. 10, pp. 2956-2965, 1970.

[15] W. Kläui, J. Bongards, and G. J. Reiß, "Neuartige Nickel(II)Komplexe zur katalytischen Copolymerisation von Ethen und Kohlenmonoxid-Polyketonsynthesen in überkritischem Kohlendioxid," Angewandte Chemie, vol. 112, no. 21, pp. 4077-4079, 2000.

[16] W. Kläui, J. Bongards, and G. J. Reiß, "Novel nickel(II) complexes for the catalytic copolymerization of ethylene and carbon monoxide: polyketone synthesis in supercritical carbon dioxide," Angewandte Chemie-International Edition, vol. 39, no. 21, pp. 3894-3896, 2000.

[17] U. Beckmann, G. Hägele, and W. Frank, "Square-planar 2toluenido(triphenylphosphane)nickel(II) complexes containing bidentate N,O ligands: an example of planar chirality," European Journal of Inorganic Chemistry, vol. 2010, no. 11, pp. 1670-1678, 2010.

[18] U. Beckmann, E. Eichberger, A. Rufińska, R. Sablong, and W. Kläui, "Nickel(II) catalysed co-polymerisation of CO and ethene: formation of polyketone vs. polyethylene-the role of co-catalysts," Journal of Catalysis, vol. 283, no. 2, pp. 143-148, 2011.

[19] U. Beckmann, M. M. Lindner, E. Eichberger, and W. Frank, "Square-planar mesitylenido(triphenylphosphane)nickel(II) complexes containing bidendate N,O-ligands: changes in catalytic efficiency upon small alterations in the ligand backbone," Journal of Organometallic Chemistry, vol. 720, pp. 73-80, 2012.

[20] E. Drent, J. A. M. van Broekhoven, and M. J. Doyle, "Efficient palladium catalysts for the copolymerization of carbon monoxide with olefins to produce perfectly alternating polyketones," Journal of Organometallic Chemistry, vol. 417, no. 1-2, pp. 235-251, 1991.

[21] E. Drent and P. H. M. Budzelaar, "Palladium-catalyzed alternating copolymerization of alkenes and carbon monoxide," Chemical Reviews, vol. 96, no. 2, pp. 663-681, 1996.

[22] D. K. Newsham, S. Borkar, A. Sen, D. M. Conner, and B. L. Goodall, "Inhibitory role of carbon monoxide in palladium(II)catalyzed nonalternating ethene/carbon monoxide copolymerizations and the synthesis of polyethene-block-poly(ethenealt-carbon monoxide)," Organometallics, vol. 26, no. 15, pp. 3636-3638, 2007.

[23] R. Luo, D. K. Newsham, and A. Sen, "Palladium-catalyzed nonalternating copolymerization of ethene and carbon monoxide: scope and mechanism," Organometallics, vol. 28, no. 24, pp. 6994-7000, 2009.

[24] O. M. Chukanova, K. A. Alpherov, and G. P. Belov, "Ethylene and carbon monoxide copolymerization catalyzed by supported palladium catalyst," Journal of Molecular Catalysis A, vol. 325, no. 1-2, pp. 60-64, 2010.

[25] C. Chen, T. M. J. Anselment, R. Fröhlich, B. Rieger, G. Kehr, and G. Erker, "o-Diarylphosphinoferrocene sulfonate palladium 
systems for nonalternating ethene-carbon monoxide copolymerization," Organometallics, vol. 30, no. 19, pp. 5348-5257, 2011.

[26] A. Vavasori, L. Ronchin, and L. Toniolo, "Carbon monoxideethene alternating copolymerization catalyzed by $[\mathrm{PdCl} 2$ (dppf)] in $\mathrm{H}_{2} \mathrm{O}-\mathrm{HCOOH}$ [dppf = 1,1 ' -bis(diphenylphosphino) ferrocene]," Journal of Molecular Catalysis A, vol. 363-364, pp. 398-403, 2012.

[27] U. Beckmann, E. Eichberger, M. Lindner, M. Bongartz, and P. C. Kunz, "Modular routes towards new N,O-bidentate ligands containing an electronically delocalised $\beta$-enaminone chelating backbone," European Journal of Organic Chemistry, no. 24, pp. 4139-4147, 2008.

[28] M. M. Lindner, U. Beckmann, E. Eichberger, G. J. Reiß, and W. Kläui, "Catalyst deactivation by $\beta$-hydride elimination: olefin and alkyne insertion into arenido-nickel(II) bonds," European Journal of Inorganic Chemistry, vol. 2010, no. 16, pp. 2352-2360, 2010.

[29] R. Berger, H. Schenkluhn, and B. Weimann, "Organometallic complex compounds, part 51. Ligand property controlled COinsertion in nickel complexes: separation of electronic and steric effects," Transition Metal Chemistry, vol. 6, no. 5, pp. 272-277, 1981.

[30] W. Hartmann and H. Singer, "Ligand property and ligand concentration control in the oligomerisation of 3-methyl-1butyn-3-ol with $\mathrm{Ni}(\mathrm{CO})_{4}$ and P-ligands as the catalytic system," Journal of Molecular Catalysis, vol. 48, no. 1, pp. 81-98, 1988.

[31] S. Wu and S. Lu, "Novel nickel(II) and cobalt(II) catalysts based on poly-salen type ligands for the dimerization of propylene," Journal of Molecular Catalysis A, vol. 197, no. 1-2, pp. 51-59, 2003.

[32] M. Lohan, B. Milde, S. Heider et al., "Synthesis, electrochemistry, spectroelectrochemistry, and solid-state structures of palladium biferrocenylphosphines and their use in $\mathrm{C}, \mathrm{C}$ cross-coupling reactions," Organometallics, vol. 31, no. 6, pp. 2310-2326, 2012.

[33] L. Piche, J. C. Daigle, R. Poli, and J. P. Claverie, "Investigation of steric and electronic factors of (arylsulfonyl)phosphane- palladium catalysts in ethene polymerization," European Journal of Inorganic Chemistry, no. 29, pp. 4595-4601, 2010.

[34] L. M. Venanzi, "Tetrahedral nickel(II) complexes and the factors determining their formation-part I. Bistriphenylphosphine nickel(II) compounds," Journal of the Chemical Society, pp. 719-724, 1958.

[35] R. G. Hayter and F. S. Humiec, "Square-planar-tetrahedral isomerism of nickel halide complexes of diphenylalkylphosphines," Inorganic Chemistry, vol. 4, no. 12, pp. 1701-1706, 1965.

[36] C. R. C. Coussmaker, M. H. Hutchinson, J. R. Mellor, L. E. Sutton, and L. M. Venanzi, "Tetrahedral nickel(II) complexes and the factors determining their formation. Part II. Complexes with dibutylphenylphosphine and butyldiphenylphosphine," Journal of the Chemical Society, pp. 2705-2713, 1961.

[37] K. A. Jensen, "Zur Stereochemie des koordinativ vierwertigen Nickels," Zeitschrift für anorganische und allgemeine Chemie, vol. 229, no. 3, pp. 265-281, 1936.

[38] K. A. Jensen, B. Nygaard, G. Elisson, and P. H. Nielsen, "Reductions with potassium graphitate I. preparation of Nickel(0) complexes of trialkyl phosphites," Acta Chemica Scandinavica, vol. 19, no. 3, pp. 768-770, 1965.
[39] P. J. Stone and Z. Dori, "Some nickel(II) complexes containing the ligands cyclohexyldiphenylphosphine, dicyclohexylphenylphosphine and tricyclohexylphosphine," Inorganica Chimica Acta, vol. 5, pp. 434-438, 1971.

[40] M. Čapka and J. Hetflejš, "Ligand effects in the Nickel catalysed addition of trichlorosilane to 1, 3-butadiene," Collection of Czechoslovak Chemical Communications, vol. 40, pp. 2073-2083, 1975.

[41] G. N. La Mar and E. O. Sherman, "A proton nuclear magnetic resonance investigation of the kinetics of tetrahedral planar isomerization of bis (n-alkyldiphenylphosphine) nickel(II) dihalides," Journal of the American Chemical Society, vol. 92, no. 9, pp. 2691-2699, 1970.

[42] L. H. Pignolet, W. D. Horrocks, and R. H. Holm, "Thermodynamics and kinetics of the planar-tetrahedral interconversion of dihalobis(diarylmethylphosphine)nickel(II) complexes," Journal of the American Chemical Society, vol. 92, no. 7, pp. 1855-1863, 1970.

[43] A. Klein, "Synthesis, spectroscopic properties, and crystal structure of 2, 2' -bipyridyldimesitylnickel(II)," Zeitschrift für anorganische und allgemeine Chemie, vol. 627, no. 4, pp. 645-650, 2001.

[44] E. Eichberger, "Einfluss von Cokatalysatoren auf die Selektivität der nickelkatalysierten Synthese von Polyketon und Polyethylen," Heinrich-Heine-Universität Düsseldorf, Düsseldorf, Germany, 2008.

[45] G. Frapper, C. X. Cu, J. F. Halet, J. Y. Saillard, and M. Kertesz, "Can carbon monoxide polymerize? A theoretical investigation of polyketone," Chemical Communications, no. 20, pp. 2011-2012, 1997.

[46] H. E. Gottlieb, V. Kotlyar, and A. Nudelman, "NMR chemical shifts of common laboratory solvents as trace impurities," The Journal of Organic Chemistry, vol. 62, no. 21, pp. 7512-7515, 1997.

[47] A. Kermagoret and P. Braunstein, "SHOP-type nickel complexes with alkyl substituents on phosphorus, synthesis and catalytic ethylene oligomerization," Dalton Transactions, no. 6, pp. 822-831, 2008.

[48] G. M. Sheldrick, SHELXS86, Program for the Solution of Crystal Structures, University of Göttingen, Göttingen, Germany, 1985.

[49] G. M. Sheldrick, SHELXS97, Program for the Refinement of Crystal Structures, University of Göttingen, Göttingen, Germany, 1997. 

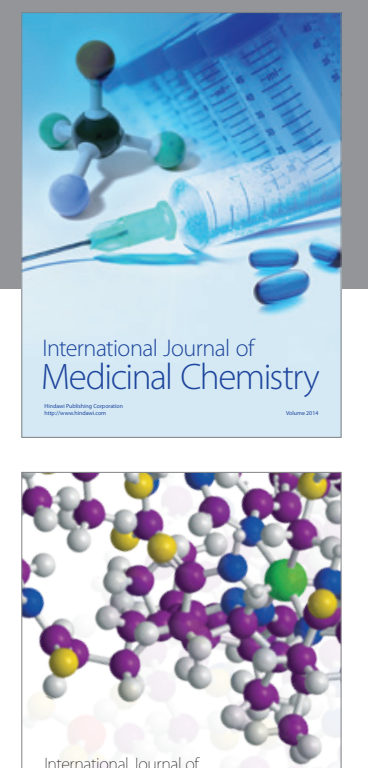

\section{Carbohydrate} Chemistry

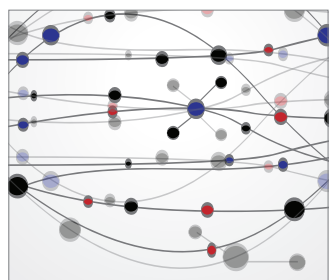

The Scientific World Journal
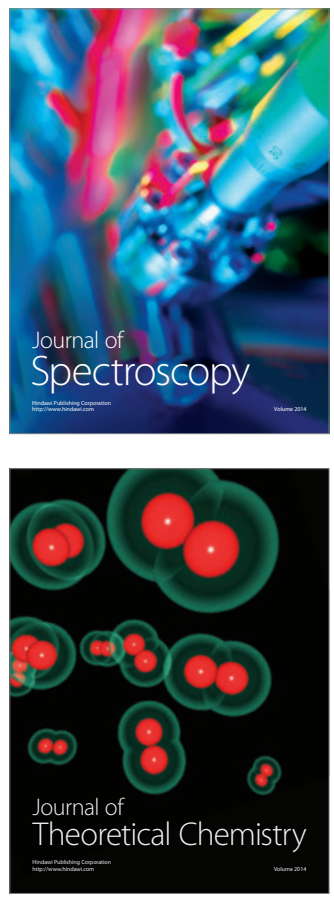
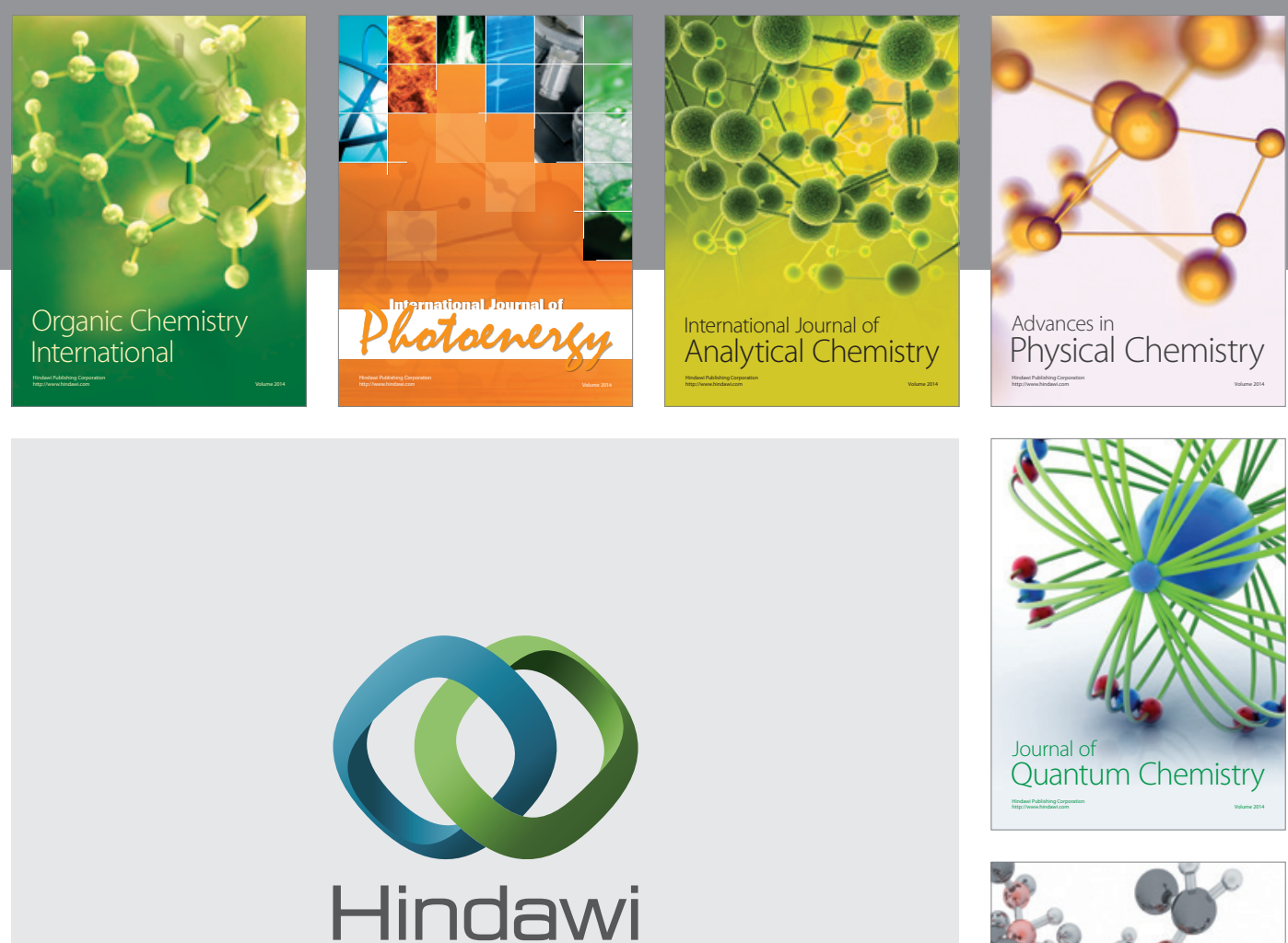

Submit your manuscripts at

http://www.hindawi.com

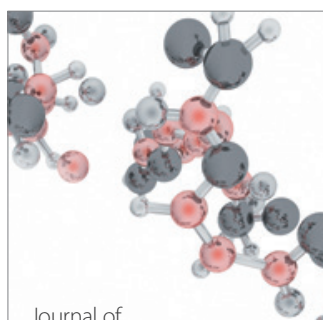

Analytical Methods

in Chemistry

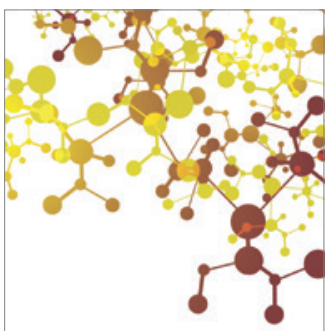

Journal of

Applied Chemistry

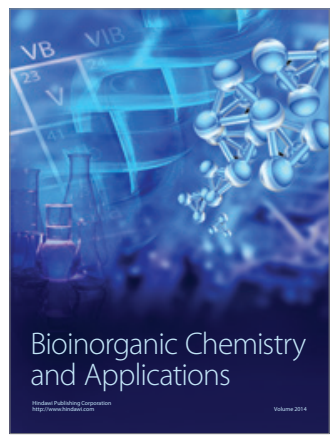

Inorganic Chemistry
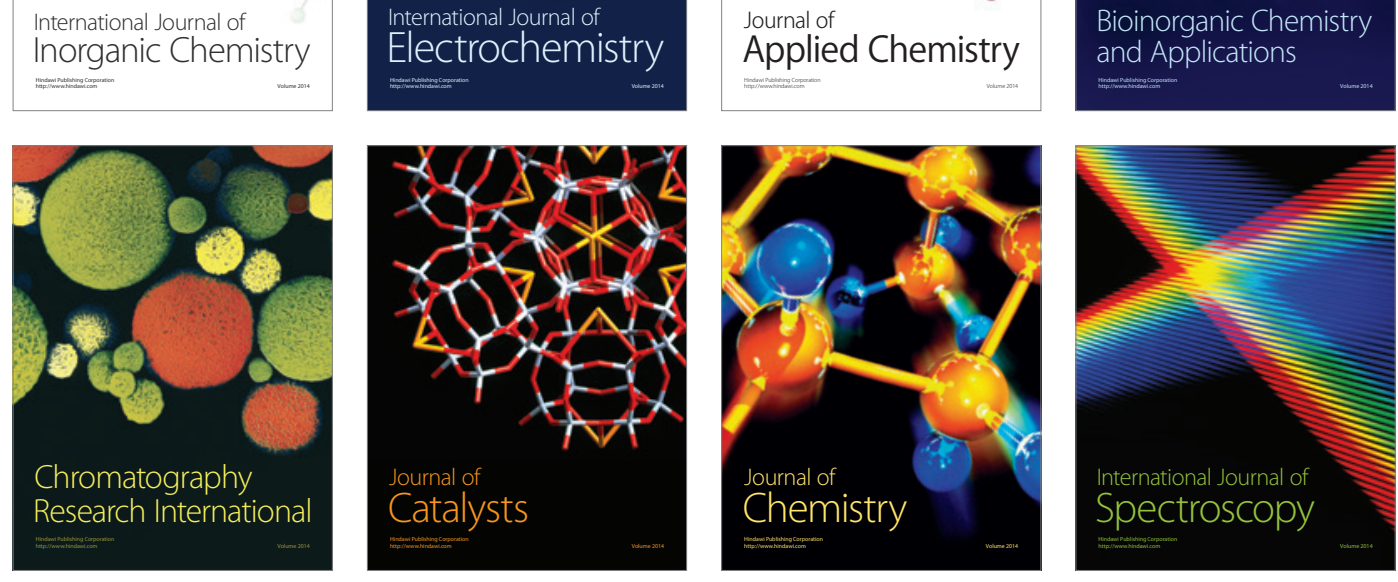